\title{
Effect of Coordination Sphere Geometry of Copper Redox Mediators on Regeneration and Recombination Behavior in Dye-Sensitized Solar Cell Applications
}

Yasemin Saygili, ${ }^{\dagger}$ Marko Stojanovic, ${ }^{\ddagger}$ Hannes Michaels, ${ }^{\S}$ Jan Tiepelt, ${ }^{\ddagger}$ Joel Teuscher,, Arianna Massaro, ${ }^{\perp}$

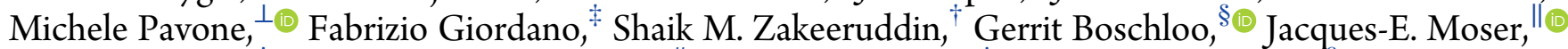
Michael Grätzel, ${ }^{\ddagger}$ Ana B. Muñoz-García, ${ }^{*}, \#$ Anders Hagfeldt,*,† and Marina Freitag, ${ }^{*}, \S(0)$

\author{
${ }^{\dagger}$ Laboratory of Photomolecular Science, Institute of Chemical Sciences and Engineering, École Polytechnique Fédérale de Lausanne, \\ 1015 Lausanne, Switzerland \\ ${ }^{\ddagger}$ Laboratory for Photonics and Interfaces, Institute of Chemical Sciences and Engineering, École Polytechnique Fédérale de \\ Lausanne, 1015 Lausanne, Switzerland \\ ${ }^{\S}$ Department of Chemistry-Ångström Laboratory, Uppsala University, 75120 Uppsala, Sweden \\ "Photochemical Dynamics Group, Ecole Polytechnique Fédérale de Lausanne, 1015 Lausanne, Switzerland \\ ${ }^{\perp}$ Department of Chemical Sciences, University of Naples Federico II, 80126 Naples, Italy \\ \#Department of Physics "Ettore Pancini”, University of Naples Federico II, 80126 Naples, Italy
}

Supporting Information

\begin{abstract}
The recombination of injected electrons with oxidized redox species and regeneration behavior of copper redox mediators are investigated for four copper complexes, $\left[\mathrm{Cu}(\mathrm{dmby})_{2}\right]^{2+/ 1+}\left(\mathrm{dmby}=6,6^{\prime}\right.$-dimethyl-2,2'bipyridine $),\left[\mathrm{Cu}(\mathrm{tmby})_{2}\right]^{2+1+}$ (tmby $=4,4^{\prime}, 6,6^{\prime}$ - tetramethyl-2,2'-bipyridine $)$, $\left[\mathrm{Cu}(\text { eto })_{2}\right]^{2+/ 1+}$ (eto $=4$-ethoxy-6,6'-dimethyl-2,2'-bipyridine), and $[\mathrm{Cu}-$ $\left.(\mathrm{dmp})_{2}\right]^{2+/ 1+}(\mathrm{dmp}=$ bis(2,9-dimethyl-1,10-phenantroline). These complexes were examined in conjunction with the D5, D35, and D45 sensitizers, having various degrees of blocking moieties. The experimental results were further supported by density functional theory calculations, showing that the low reorganization energies, $\lambda$, of tetra-coordinated $\mathrm{Cu}(\mathrm{I})$ species $(\lambda=0.31-0.34 \mathrm{eV})$ allow efficient regeneration of the oxidized dye at driving forces down to approximately $0.1 \mathrm{eV}$. The regeneration electron transfer reaction is in the Marcus normal regime. However, for $\mathrm{Cu}(\mathrm{II})$ species, the presence of 4-tert-

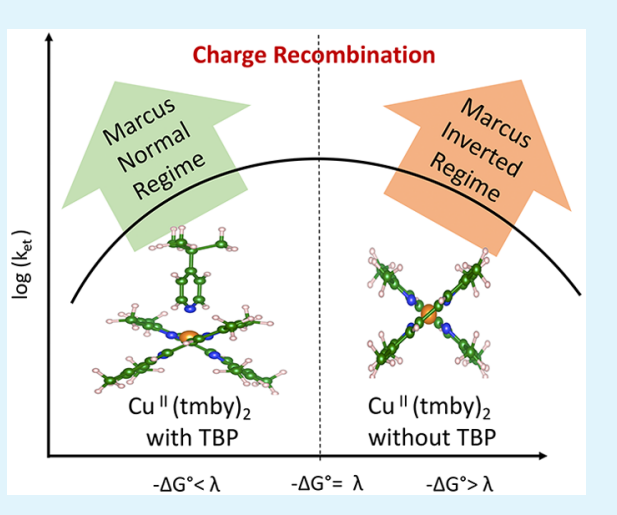
butylpyridine (TBP) in electrolyte medium results in penta-coordinated complexes with altered charge recombination kinetics $(\lambda=1.23-1.40 \mathrm{eV})$. These higher reorganization energies lead to charge recombination in the Marcus normal regime instead of the Marcus inverted regime that could have been expected from the large driving force for electrons in the conduction band of $\mathrm{TiO}_{2}$ to react with $\mathrm{Cu}(\mathrm{II})$. Nevertheless, the recombination resistance and electron lifetime values were higher for the copper redox species compared to the reference cobalt redox mediator. The DSC devices employing D35 dye with $\left[\mathrm{Cu}(\mathrm{dmp})_{2}\right]^{2+/ 1+}$ reached a record value for the open circuit voltage of $1.14 \mathrm{~V}$ without compromising the short circuit current density value. Even with the D5 dye, which lacks recombination preventing steric units, we reached $7.5 \%$ efficiency by employing $\left[\mathrm{Cu}(\mathrm{dmp})_{2}\right]^{2+1+}$ and $\left[\mathrm{Cu}(\mathrm{dmby})_{2}\right]^{2+/ 1+}$ at $\mathrm{AM} 1.5 \mathrm{G}$ full sun illumination with open circuit voltage values as high as $1.13 \mathrm{~V}$.
\end{abstract}

KEYWORDS: dye-sensitized solar cells, copper redox mediators, copper electrolytes, solar energy, recombination

\section{INTRODUCTION}

Based on the increasing energy demand and consequent environmental concerns, photovoltaic technologies attract a lot of attention as clean energy sources. The related power conversion efficiencies (PCEs) of various solar energy harvesting units continue to increase, targeting the Shockley-Queisser limit. ${ }^{1,2}$ To expand the commercialization and integration of photovoltaic devices in various applications, low costs and easy fabrication techniques will define the success of each competing technology. From this point of view, dye- sensitized solar cells (DSCs) ${ }^{3}$ can be foreseen as cost-efficient candidates with multifarious manufacturing possibilities and short energy-payback times. Variable color options, sustainable processability on a variety of substrates, ${ }^{4}$ and high performance of this technology under diffuse light conditions could be used to power low capacity portable electronics. Especially, the

Received: June 12, 2018

Accepted: August 23, 2018

Published: August 23, 2018 

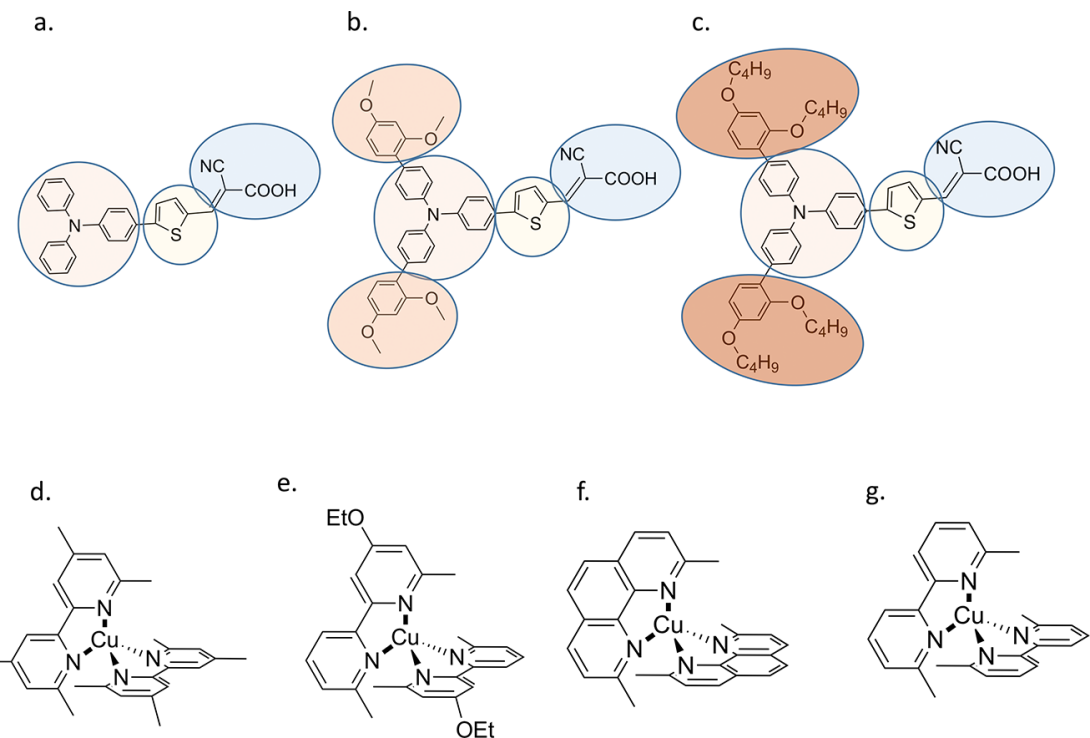

Figure 1. Molecular structures of (a) D5, (b) D45, and (c) D35 dyes and (d) $\left[\mathrm{Cu}(\text { tmby })_{2}\right]^{2+/ 1+},(\mathrm{e})\left[\mathrm{Cu}(\mathrm{eto})_{2}\right]^{2+/ 1+},(\mathrm{f})\left[\mathrm{Cu}(\mathrm{dmp})_{2}\right]^{2+/ 1+}$, and $(\mathrm{g})$ $\left[\mathrm{Cu}(\mathrm{dmby})_{2}\right]^{2+/ 1+}$ complexes.

recent development of DSCs reveal that these devices have outstandingly high performance under ambient light, reaching $32 \%$ PCE under 1000 lux fluorescent light source. ${ }^{5}$ For the same system ${ }^{5}$ the highest PCE was reported to be $13.1 \%$ under standard air mass 1.5 global (AM1.5G) conditions.

In a conventional DSC, the photoelectrode consists of dye molecules anchored to a wide band gap semiconductor (generally $\mathrm{TiO}_{2}$ ). Following light absorption, the dye molecules inject electrons to the conduction band of $\mathrm{TiO}_{2}$, and the oxidized dye molecules are regenerated back with a redox mediator. The cycle is completed at a counter electrode which has catalytic activity so as to reduce the oxidized redox species. $^{3}$ In a DSC system, open circuit voltage $\left(V_{\text {oc }}\right)$ is determined by the difference between the quasi-Fermi level of the semiconductor and electrolyte redox potential. In order to achieve high $V_{\mathrm{OC}}$ values, electron injection and dye regeneration overpotentials should be reduced. ${ }^{6,7}$

In the early stages of DSC research, iodide/tri-iodide electrolyte was conventionally used. ${ }^{4}$ For this redox mediator, the redox potential is around $0.3-0.4 \mathrm{~V}$ vs standard hydrogen electrode (SHE). ${ }^{8}$ Iodide/tri-iodide redox couple was reported to be advantageous in terms of the suppressed recombination of electrons with tri-iodide. However, as a two-electron redox couple, large internal potential losses occur in the dye regeneration step, which also limits the photovoltage outputs. The disadvantages of iodide/tri-iodide electrolytes were overcome after the introduction of one-electron transfer cobalt coordination complexes. The redox potential of these metal complexes can be easily tuned via different ligand modifications. ${ }^{9,10}$ Therefore, by having more positive electrolyte redox potentials, higher photovoltage outputs became feasible. However, for cobalt redox mediators, the redox potential of the electrolyte became a matter of compromise as the dye regeneration rates decreased and recombination rates increased with increasing redox potentials. ${ }^{11}$ The recombination of electrons between the $\mathrm{TiO}_{2}$ and the redox mediator was reported to be much faster with cobalt redox mediators employed. ${ }^{12}$ In order to reduce this recombination, surface passivation $^{13,14}$ techniques have been applied. The most efficient method to prevent the recombination appeared as the modification of dye structures via attachment of bulky electron rich substituents ${ }^{12,15-19}$ which, however, can be problematic in terms of dye loading.

The $(\mathrm{Cu}(\mathrm{I}) / \mathrm{Cu}(\mathrm{II}))$ one-electron transfer complexes were studied for both liquid ${ }^{20-25}$ and solid ${ }^{26,27}$ state DSC applications. In our recent study, the photovoltaic performance of bis(2,9-dimethyl-1,10-phenantroline)copper(I)/-copper(II) $\left(\left[\mathrm{Cu}(\mathrm{dmp})_{2}\right]^{2+/ 1+}\right)$ and two copper bipyridyl complexes $\left(\left[\mathrm{Cu}(\mathrm{dmby})_{2}\right]^{2+/ 1+}\left(0.97 \mathrm{~V}\right.\right.$ vs SHE; dmby $=6,6^{\prime}$-dimethyl$2,2^{\prime}$-bipyridine $)$ and $\left[\mathrm{Cu}(\text { tmby })_{2}\right]^{2+/ 1+}(0.87 \mathrm{~V}$ vs SHE; tmby $=$ $4,4^{\prime}, 6,6^{\prime}$ - tetramethyl-2,2'-bipyridine)) were efficiently utilized as redox mediators in liquid state DSCs. ${ }^{28} \mathrm{We}$ previously demonstrated, that, with Y123 sensitizer, we can reach values above $10 \%$ PCE at AM 1.5G full sun illumination. $V_{\text {oc }}$ stays above $1.0 \mathrm{~V}$ without compromising photocurrent densities. Despite the small driving force left for dye regeneration, the photocurrent was maintained due to fast and efficient dye regeneration $(2-3 \mu \mathrm{s})$ which is faster than the recombination of electrons between $\mathrm{TiO}_{2}$ and the oxidized dye. ${ }^{28}$ The $\left[\mathrm{Cu}(\mathrm{tmby})_{2}\right]^{2+/ 1+}$ complex has also been effectively used in cosensitized systems ${ }^{29}$ and quasi-solid state DSCs. ${ }^{30}$

Despite reaching high PCE values with copper complexes based DSCs, the processes responsible were insufficiently investigated and understood. Herein, we studied the recombination and regeneration behaviors of the $[\mathrm{Cu}-$ $\left.(\mathrm{dmby})_{2}\right]^{2+/ 1+},\left[\mathrm{Cu}(\text { tmby })_{2}\right]^{2+/ 1+},\left[\mathrm{Cu}(\text { eto })_{2}\right]^{2+/ 1+}$ (eto $=4-$ ethoxy-6,6'-dimethyl-2,2'-bipyridine), and $\left[\mathrm{Cu}(\mathrm{dmp})_{2}\right]^{2+/ 1+}$ together with sensitizers, having various degrees of blocking side chains. We introduce a new copper complex, $[\mathrm{Cu}-$ (eto $\left.)_{2}\right]^{2+/ 1+}$, in order to have similar redox potential as $\left[\mathrm{Cu}(\text { tmby })_{2}\right]^{2+/ 1+}$ and understand solely the effect of ligand structure on dye regeneration and charge recombination by comparing the data of $\left[\mathrm{Cu}(\text { eto })_{2}\right]^{2+/ 1+}$ and $\left[\mathrm{Cu}(\mathrm{tmby})_{2}\right]^{2+/ 1+}$. The chemical structures of copper complexes and D5, D45, and D35 dyes are given in Figure 1. The D5, D35, and D45 dyes consist of a triphenylamine electron donor, thiophene chain extending $\pi$-conjugation, and cyanoacrylic acid as the anchoring group. The D5 dye has no bulky substituents to prevent electron recombination, but D35 and D45 dyes include bulky alkoxy electron donating substituents. Employing 
these three sensitizers, the dye regeneration kinetics were investigated via transient absorption spectroscopy and photoinduced absorption spectroscopy experiments. To further investigate the recombination behavior of the injected electrons in $\mathrm{TiO}_{2}$ and electrolyte, we performed electrical impedance spectroscopy measurements and small amplitude light-modulation technique (Toolbox) measurements. In addition, a detailed density functional theory analysis was provided to understand the effect of molecular configuration on electron transfer processes.

According to transient absorption spectroscopy, the oxidized dye molecules are regenerated close to unity yields (in the microsecond range) with very low driving forces (i.e., $0.1 \mathrm{eV}$ ) by employing the four copper redox mediators. The calculated activation energy values for the regeneration of the oxidized D5 and D45 dyes were found to be similar to the values of $\left[\mathrm{Co}(\mathrm{bpy})_{3}\right]^{3+/ 2+}$. This finding explains the reason for having similar current density values with $\left[\mathrm{Co}(\mathrm{bpy})_{3}\right]^{3+/ 2+}$ and copper redox couples.

Contrary to $\mathrm{Cu}(\mathrm{I})$ species, the $\mathrm{Cu}(\mathrm{II})$ counterparts tend to be penta-coordinated by accepting 4-tert-butylpyridine (TBP) (or alternatively some counterions) as the third ligand. ${ }^{28,31-35}$ By means of density functional theory calculations, we proved that TBP-coordinated $\mathrm{Cu}$ (II) species have higher reorganization energies in comparison to $\mathrm{Cu}(\mathrm{I})$ counterparts. In the presence of $\mathrm{TBP}$, the formal $\mathrm{Cu}(\mathrm{II}) / \mathrm{Cu}(\mathrm{I})$ redox potential shifts negatively by several tens of millivolts. ${ }^{28}$ These findings show that the charge recombination stays in Marcus normal regime. The experimentally derived electron lifetimes, extracted charge values, and recombination resistances were compared to $\left[\mathrm{Co}(\mathrm{bpy})_{3}\right]^{3+/ 2+}$. In accordance with calculated parameters, it is shown that even though the driving force for recombination in copper redox mediators is higher compared to cobalt electrolyte, the copper electrolytes give higher recombination resistance and higher electron lifetimes in most of the cases. Due to the higher resistance for recombination, the effect of dye structure becomes less significant for the copper complexes, which can be clearly observed for the devices sensitized with D5 dye. It is also shown that, in the absence of TBP, the calculated reorganization energy values suggest a Marcus inverted regime for recombination.

\section{EXPERIMENTAL PROCEDURE}

All chemicals were purchased from Sigma-Aldrich, HetCat, Dyenamo, and TCI Chemicals and were used without further purification, unless otherwise stated.

Synthesis of 4-Ethoxy-6,6'-dimethyl-2,2'-bipyridine Ligand. The detailed synthetic procedure for eto ligand is given in Supporting Information (SI), Figure S1.

Synthesis of Copper Complexes. $\left[\mathrm{Cu}(\mathrm{dmby})_{2}\right]^{2+/ 1+},[\mathrm{Cu}-$ $\left.(\mathrm{tmby})_{2}\right]^{2+/ 1+}$, and $\left[\mathrm{Cu}(\mathrm{dmp})_{2}\right]^{2+/ 1+}$ were produced as previously reported. ${ }^{27,28}$ Detailed complexation procedures for $\left[\mathrm{Cu}(\text { eto })_{2}\right]-$ $[\mathrm{TFSI}]$ and $\left[\mathrm{Cu}(\text { eto })_{2}\right][\mathrm{TFSI}]_{2}$ complexes are given in Figure S2. For $\left[\mathrm{Cu}(\mathrm{dmp})_{2}\right][\mathrm{TFSI}], 1$ equiv of $\mathrm{CuI}$ was mixed with 4 equiv of neocuproine hydrate in ethanol, under inert atmosphere at room temperature for $2 \mathrm{~h}$. A 4 equiv amount of LiTFSI was added to the solution, and mixing continued for an additional $2 \mathrm{~h}$.

A red crystalline powder was obtained by filtering the stirred solution and was washed with water and diethyl ether. To produce $\left[\mathrm{Cu}(\mathrm{dmp})_{2}\right][\mathrm{TFSI}]_{2}$ complex, $\left[\mathrm{Cu}(\mathrm{dmp})_{2}\right][\mathrm{TFSI}]$ was oxidized by addition of $\mathrm{NOBF}_{4}$. Briefly, $\left[\mathrm{Cu}(\mathrm{dmp})_{2}\right][\mathrm{TFSI}]$ was dissolved in acetonitrile and 1 equiv of $\mathrm{NOBF}_{4}$ was added to the solution. After 30 min, 5 equiv of LiTFSI was added to the mixture and it was further stirred for $2 \mathrm{~h}$ at room temperature and inert atmosphere. The solvent was removed by rotatory evaporation and the crude product redissolved in a minimum amount of dichloromethane. $\left[\mathrm{Cu}(\mathrm{dmp})_{2}\right]$ $[\mathrm{TFSI}]_{2}$ was precipitated in diethyl ether, collected by filtration, and washed with diethyl ether, resulting in a violet powder.

For complexation of $\left[\mathrm{Cu}(\mathrm{dmby})_{2}\right][\mathrm{TFSI}],\left[\mathrm{Cu}(\mathrm{tmby})_{2}\right][\mathrm{TFSI}]$, and $\left[\mathrm{Cu}(\text { eto })_{2}\right][\mathrm{TFSI}] 1$ equiv of $\mathrm{CuI}$ was mixed with 3 equiv of dmby, tmby, and eto ligands, respectively, in $20 \mathrm{~mL}$ of ethanol under inert atmosphere at room temperature. After $2 \mathrm{~h}, 5$ equiv of LiTFSI was added to the solution and stirring continued for additional $2 \mathrm{~h}$. The resulting $\mathrm{Cu}(\mathrm{I})$ complexes were filtrated and collected as red powder and washed with water and diethyl ether.

In order to produce $\left[\mathrm{Cu}(\mathrm{dmby})_{2}\right][\mathrm{TFSI} / \mathrm{Cl}],\left[\mathrm{Cu}(\mathrm{tmby})_{2}\right][\mathrm{TFSI} /$ $\mathrm{Cl}]$, and $\left[\mathrm{Cu}(\text { eto })_{2}\right][\mathrm{TFSI} / \mathrm{Cl}], 1$ equiv of $\mathrm{CuCl}_{2}$ was mixed with 3 equiv of dmby, tmby, or eto ligands, respectively, in $20 \mathrm{~mL}$ of ethanol under nitrogen atmosphere at room temperature. After $2 \mathrm{~h}, 5$ equiv of LiTFSI and $5 \mathrm{~mL}$ of deionized water were added to the mixture. The solution was stirred for an additional $2 \mathrm{~h}$, and the complexes were collected by filtration as green powders and washed with water and diethyl ether.

Electrochemical Characterization. Three-electrode cyclic voltammetry measurements were performed using $\mathrm{Ag} / \mathrm{AgCl} /$ saturated $\mathrm{LiCl}$ (ethanol) as reference electrode and glassy carbon working electrode under nitrogen with Autolab Pgstat-30 potentiostat. $\left[\mathrm{Cu}(\text { eto })_{2}\right]^{1+}$ was dissolved in acetonitrile with $0.1 \mathrm{M}$ LiTFSI. Redox potentials were referenced with respect to ferrocene.

$\mathrm{UV} /$ vis absorption data for $\left[\mathrm{Cu}(\text { eto })_{2}\right]^{1+}$ and $\left[\mathrm{Cu}(\text { eto })_{2}\right]^{2+}$ were obtained by a Hewlett-Packard 8453 diode array spectrometer. The corresponding extinction coefficients were calculated using the Lambert-Beer law.

Device Fabrication. The photoanodes were prepared on FTO glasses (NSG-10, Nippon Sheet Glass) in the following process order: Cleaning with a detergent solution (Deconex) in ultrasonic bath and $\mathrm{UV} / \mathrm{O}_{3}$ treatment (Model No. 256-220, Jelight Co., Inc.), $\mathrm{TiCl}_{4}$ treatment, screen printing with $30 \mathrm{~nm}$ diameter sized $\mathrm{TiO}_{2}$ particles (Dyesol) (5 $\mu \mathrm{m}$ transparent layer) and $400 \mathrm{~nm}$ sized particles $(5 \mu \mathrm{m}$ scattering layer), sintering, and $\mathrm{TiCl}_{4}$ post-treatment.

A $0.1 \mathrm{mM}$ dye solutions (Dyenamo $\mathrm{AB}$ ) were prepared in tertbutanol/acetonitrile (1:1 (v:v)) mixture. $0.4 \mathrm{mM}$ chenodeoxycholic acid was used in the dye solutions as an additive in order to prevent aggregation. Working electrodes were dipped for $16 \mathrm{~h}$ in these solutions. FTO glasses (TEC 6, Pilkington) were coated with PEDOT via electrodeposition ${ }^{36}$ and used as counter electrodes. ${ }^{28} 25 \mu \mathrm{m}$ Surlyn spacer (Dupont) was used for assembling the working electrode and counter electrodes and electrolyte encapsulation. The electrolytes were prepared with $0.2 \mathrm{M} \mathrm{Cu}$ (I) and $0.06 \mathrm{M} \mathrm{Cu}$ (II) complexes, 0.1 M LiTFSI, and 0.6 M TBP in acetonitrile. A detailed device preparation description can be found in the publication by Saygili et al. ${ }^{28}$

Solar Cell Characterization. The current-voltage $(I-V)$ characteristics for the DSC devices were obtained by using a 450 W xenon light source (Oriel, USA). In order to reduce the spectral mismatches between AM 1.5G and the light source, a Schott K113 Tempax filter (Präzisions Glas \& Optik GmbH) was used. A Keithley model 2400 digital source meter (Keithley, USA) was used to apply an external potential bias to the devices and measure the resulting current. All the devices were measured with a mask of $0.158 \mathrm{~cm}^{2}$ area.

Incident Photon to Current Conversion Efficiency. Incident photon to current conversion efficiency (IPCE) data were acquired using a computer-modulated setup consisting a xenon light source (Spectral Products ASB-XE-175), a monochromator (Spectral Products CM110), and a multimeter (Keithley 2700). A certified reference solar cell (Fraunhofer ISE) was used as reference.

Photoinduced Absorption Spectroscopy. The photoinduced absorption spectra of the various cells were recorded using excitation from a square-wave-modulated blue LED (Luxeon Star $1 \mathrm{~W}$, Royal Blue, $460 \mathrm{~nm}$ ), and white probe light from a tungsten-halogen lamp $(20 \mathrm{~W})$ was used as an illumination source. The transmitted light was focused into a monochromator (Acton Research Corp. SP-150) and detected using a UV-enhanced Si photodiode, connected to a lock-in amplifier (Stanford Research Systems Model SR830). LED excitation 

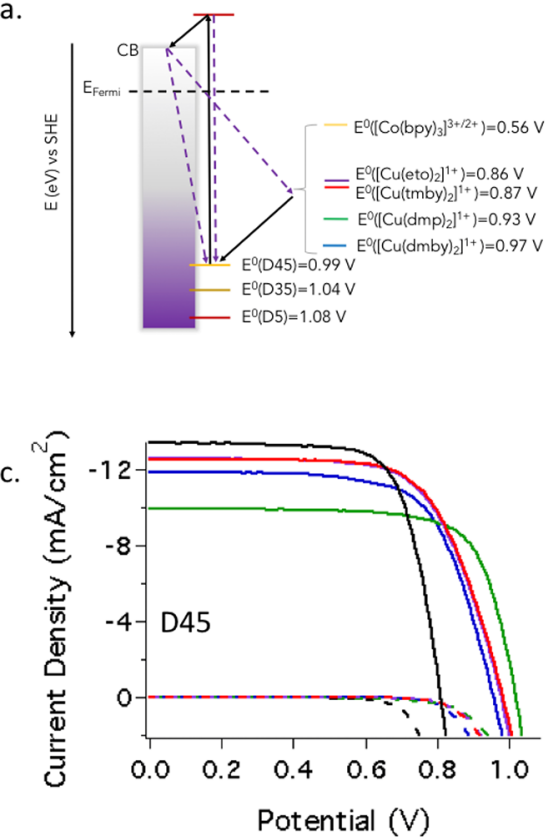

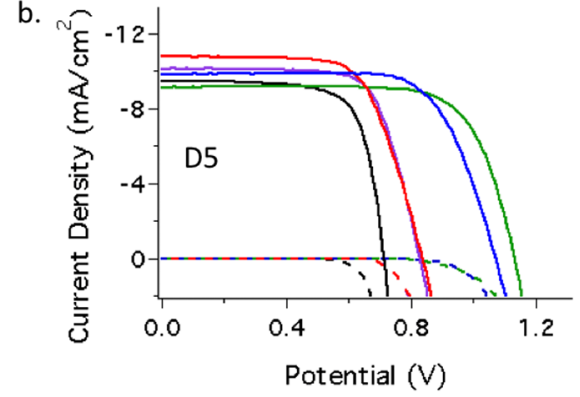

d.

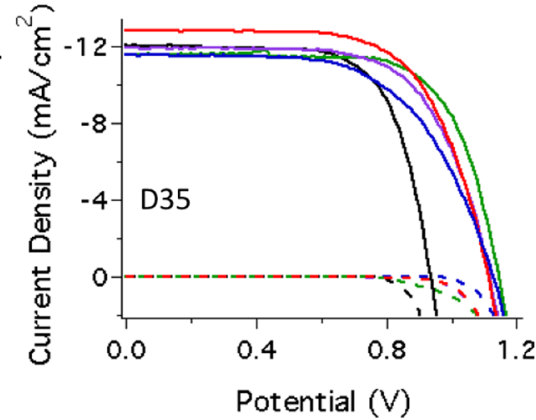

Figure 2. (a) HOMO levels of D5, D35, and D45 dyes and formal redox potentials of the $\mathrm{Cu}(\mathrm{I})$ species and (b-d) current density vs applied potential curves under dark and $100 \mathrm{~W} / \mathrm{cm}^{2}$ AM1.5G illumination for DSCs devices measured with a mask aperture of $0.158 \mathrm{~cm}^{2}$. $\left(\left[\mathrm{Cu}(\mathrm{dmby})_{2}\right]^{2+/ 1+}\right.$, blue; $\left[\mathrm{Cu}(\text { tmby })_{2}\right]^{2+/ 1+}$, red; $\left[\mathrm{Cu}(\text { eto })_{2}\right]^{2+/ 1+}$, purple; $\left[\mathrm{Cu}(\mathrm{dmp})_{2}\right]^{2+/ 1+}$, green; $\left[\mathrm{Co}(\mathrm{bpy})_{3}\right]^{3+/ 2+}$, black $)$.

intensity was approximately $80 \mathrm{Wm}^{2-}$, and the modulation intensity was $9.33 \mathrm{~Hz}$.

Transient Absorption Spectroscopy. Nano-microsecond laser flash photolysis was applied to samples loaded with D45, D35, or D5 dyes. The samples for transient absorption spectroscopy measurement were prepared by sandwiching the $\mathrm{TiO}_{2}$ films and electrolytes between two nonconductive glasses. Transparent $\mathrm{TiO}_{2}$ films of $4 \mu \mathrm{m}$ thickness were screen printed on a glass substrate. In order to have smaller amounts of dye loading on $\mathrm{TiO}_{2}, 0.01 \mathrm{mM}$ amounts of D5, $\mathrm{D} 35$, and $\mathrm{D} 45$ dye solutions were used. The $\mathrm{TiO}_{2}$ electrodes were dipped into the dye solution for $16 \mathrm{~h}$. The $\mathrm{TiO}_{2}$ electrodes and glass substrates were assembled with $35 \mu \mathrm{m}$ Surlyn (Dupont) spacer, similar to DSC fabrication. The electrolyte was injected through predrilled holes in the glass substrate. The samples were excited by 7 ns (fwhm) pulsed laser light produced at a repetition rate of $20 \mathrm{~Hz}$ by a frequency-doubled Qswitched Nd:YAG laser $\left(\lambda_{\mathrm{ex}}=532 \mathrm{~nm}\right)$. The laser fluence on the sample was kept at a low level $\left(50 \mu \mathrm{J} \mathrm{cm}^{-2}\right.$ per pulse) to ensure that, on average, less than one electron is injected per $\mathrm{TiO}_{2}$ nanoparticle per pulse. The probe light consists of a halogen lamp passed through a monochromator, focused onto the sample and collected in a second monochromator at $1200 \mathrm{~nm}$. The detector is a fast InGaAs diode (SM05PD5A, Thorlabs) connected to a digital oscilloscope. Typical data are averaged over 1000 laser shots.

Electrochemical Impedance Spectroscopy. Impedance measurements were carried out with a BioLogic SP300 potentiostat. A sinusoidal potential perturbation was applied within a frequency range of $7 \mathrm{MHz}$ to $0.1 \mathrm{~Hz}$. The bias potential was manipulated between $0 \mathrm{~V}$ and $V_{\text {oc }}$ with $50 \mathrm{mV}$ increments. The impedance data were fitted with ZView software (Scribner Associates) according to the transmission line method. ${ }^{37}$

Electron Lifetime and Charge Extraction Measurements. Electron lifetimes and charge extraction of the devices were measured via DYENAMO Toolbox System. This setup mainly includes a white LED light source (Seoul Semiconductors), a 16-bit resolution digital acquisition board (National Instruments), and a current amplifier (Thorlabs PDA200C). To extract charges, the DSCs were kept at open circuit conditions and illuminated by the LED light. The light source was turned off after $1 \mathrm{~s}$, and the device was switched to short circuit condition. The total extracted charge was integrated over time. By using different light intensities, the complete charge-potential curve was obtained. In electron lifetime measurements, the light source was controlled by a modulated current superimposed on a bias current and the open circuit voltage response was measured. The lifetimes were obtained by fitting parameters of open circuit voltage response curves.

Rest Potential Measurements. The electrolyte solutions were investigated with homemade paper-plug electrodes. The rest potential of the redox couple (with TBP) was measured with a Pt wire vs an $\mathrm{Ag} / \mathrm{AgCl}$ reference electrode. A $0.1 \mathrm{M}$ amount of tetrabutylammonium hexafluorophosphate in acetonitrile solution served as supporting electrolyte. The data were calibrated with respect to ferrocene.

Density functional theory calculations. The dye regeneration and charge recombination processes have been investigated also by carrying out state-of-the-art density functional theory (DFT) calculations with the reliable B3LYP hybrid density functional ${ }^{38}$ and the well-known polarizable continuum model (PCM) to take into account the acetonitrile solvent medium. ${ }^{39}$ To account for the dispersion interaction that is neglected in standard DFT, we applied the DFT-D3 approach of Grimme et al. with the BJ damping scheme. ${ }^{40}$ Molecular frequencies have been computed within the harmonic approximation and were used to obtain zero-point vibrational frequencies and other thermodynamic parameters at standard conditions. ${ }^{41}$ The vertical excitation energies and the excited state properties of D5 and D45 dyes have been computed by applying the time-dependent DFT (TD-DFT) approach with the CAM-B3LYP density functional ${ }^{42}$ that provides reliable predictions for push-pull organic dyes for DSSC applications. ${ }^{43}$ In all these calculations we exploited the Stuttgart/Dresden effective core potential and basis set (SDD) for copper ${ }^{44}$ and the $6-31++G(d, p)^{45}$ for all of the other atoms of ligands and TBP. Further details on the methods for computing redox potentials and reorganization energies can be found in refs 25 and 28.

\section{RESULTS AND DISCUSSION}

Electrochemical and Spectroscopic Data of Novel $\mathrm{Cu}^{\prime}$ (eto) ${ }_{2}$ and $\mathrm{Cu}^{\prime \prime}$ (eto) $)_{2}$. The formal redox potential of the novel $\left[\mathrm{Cu}(\text { eto })_{2}\right]^{2+/ 1+}$ complex was determined by threeelectrode cyclic voltammetry measurement. By omitting the 
Table 1. J-V Characteristics for D5-, D35-, and D45-Sensitized DSC Devices Employing $\left[\mathrm{Cu}(\mathrm{tmby})_{2}\right]^{2+/ 1+},\left[\mathrm{Cu}(\text { eto })_{2}\right]^{2+/ 1+}$, $\left[\mathrm{Cu}(\mathrm{dmby})_{2}\right]^{2+/ 1+},\left[\mathrm{Cu}(\mathrm{dmp})_{2}\right]^{2+/ 1+}$, and $\left[\mathrm{Co}(\mathrm{bpy})_{3}\right]^{3+/ 2+}$ Electrolytes (All Electrolytes Have Same Concentration of Additives $0.1 \mathrm{M}$ LiTFSI and $0.6 \mathrm{M}$ TBP)

\begin{tabular}{|c|c|c|c|c|c|c|c|c|c|c|c|c|}
\hline \multirow[b]{2}{*}{ redox couple } & \multicolumn{4}{|c|}{ D5 } & \multicolumn{4}{|c|}{ D45 } & \multicolumn{4}{|c|}{ D35 } \\
\hline & $V_{\mathrm{oc}}(\mathrm{V})$ & $\left(\mathrm{mA} \mathrm{cm}^{-2}\right)$ & FF & PCE (\%) & $V_{\mathrm{oc}}(\mathrm{V})$ & $\left(\mathrm{mA} \mathrm{cm}^{J_{\mathrm{sc}}}\right)$ & FF & PCE (\%) & $V_{\mathrm{oc}}(\mathrm{V})$ & $\left(\mathrm{mA} \mathrm{cm}^{-2}\right)$ & FF & PCE (\%) \\
\hline$\left[\mathrm{Co}(\mathrm{bpy})_{2}\right]^{3+/ 2+}$ & 0.713 & 9.45 & 0.728 & 4.91 & 0.810 & 13.40 & 0.730 & 7.93 & 0.936 & 12.05 & 0.691 & 7.80 \\
\hline$\left[\mathrm{Cu}(\mathrm{tmby})_{2}\right]^{2+/ 1+}$ & 0.837 & 10.79 & 0.674 & 6.10 & 0.984 & 12.52 & 0.673 & 8.3 & 1.11 & 12.81 & 0.661 & 9.44 \\
\hline$\left[\mathrm{Cu}(\text { eto })_{2}\right]^{2+/ 1+}$ & 0.828 & 10.12 & 0.715 & 6.00 & 0.978 & 12.59 & 0.667 & 8.21 & 1.12 & 11.93 & 0.663 & 8.84 \\
\hline$\left[\mathrm{Cu}(\mathrm{dmp})_{2}\right]^{2+/ 1+}$ & 1.13 & 9.02 & 0.736 & 7.53 & 1.02 & 9.90 & 0.741 & 7.48 & 1.14 & 11.40 & 0.706 & 9.22 \\
\hline$\left[\mathrm{Cu}(\mathrm{dmby})_{2}\right]^{2+/ 1+}$ & 1.07 & 9.85 & 0.712 & 7.53 & 0.956 & 11.85 & 0.680 & 7.71 & 1.13 & 11.53 & 0.602 & 7.84 \\
\hline
\end{tabular}
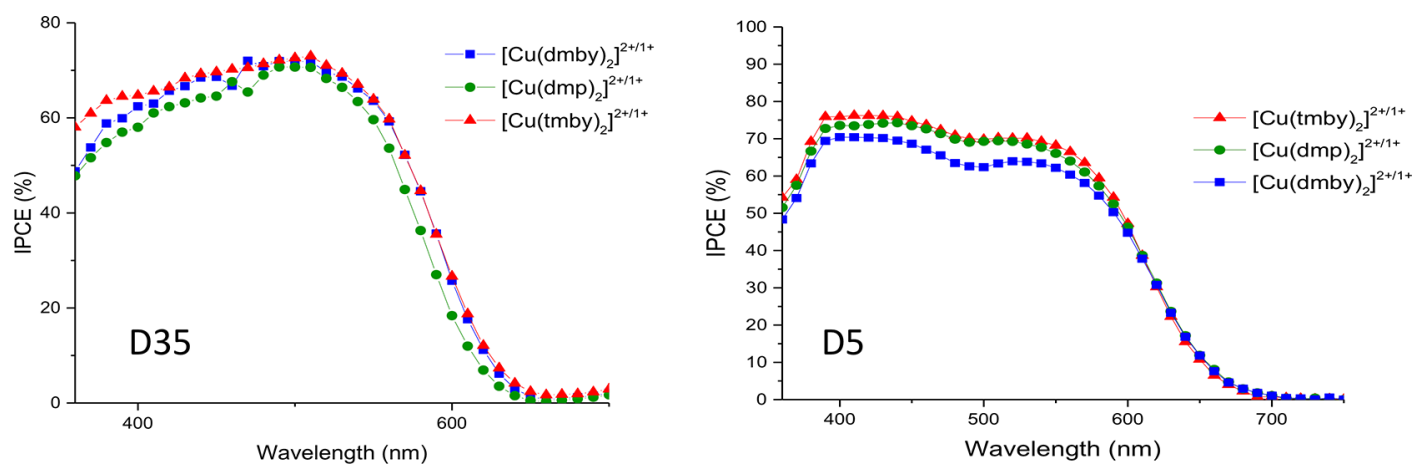

Figure 3. IPCE spectra of D35- and D5-sensitized DSC devices employing the three copper complex electrolytes.

activity coefficient differences, the redox potential of this complex can be approximated as $0.86 \mathrm{~V}$ vs SHE (Figure S3). The absorption spectra of the $\left[\mathrm{Cu}(\text { eto })_{2}\right]^{1+}$ and $\left[\mathrm{Cu}(\text { eto })_{2}\right]^{2+}$ are given in (Figure S4). For $\left[\mathrm{Cu}(\text { eto })_{2}\right]^{1+}$, the extinction coefficient is found to be $1750 \mathrm{M}^{-1} \mathrm{~cm}^{-1}$ at $450 \mathrm{~nm}$, suggesting a metal-to-ligand charge transfer (MLCT) transition. For $\left[\mathrm{Cu}(\text { eto })_{2}\right]^{2+}$, the absorption peaks are observed in the UV region, attributed to the $\pi \rightarrow \pi^{*}$ transitions, with an extinction coefficient value of $1400 \mathrm{M}^{-1} \mathrm{~cm}^{-1}$ at $360 \mathrm{~nm}$.

Photovoltaic Performance. The energy levels of the D5, $\mathrm{D} 35$, and $\mathrm{D} 45$ sensitizers and those of $\left[\mathrm{Cu}(\mathrm{tmby})_{2}\right]^{1+}$, $\left[\mathrm{Cu}(\mathrm{dmby})_{2}\right]^{1+},\left[\mathrm{Cu}(\mathrm{dmp})_{2}\right]^{1+}$, and $\left[\mathrm{Co}(\mathrm{bpy})_{3}\right]^{3+/ 2+}$ complexes and the photocurrent-voltage characteristics of the DSC devices employing these materials are given in Figure $2 \mathrm{a}$ and Figure $2 \mathrm{~b}-\mathrm{d}$, respectively. The power conversion efficiencies $(\eta)$ are calculated by eq 1 , where $J_{s c}$ is the photocurrent densities, $V_{\text {oc }}$ is the open circuit voltages, FF is the fill factors, and $I_{0}$ is the incident light intensity. The photovoltaic data are provided in Table 1 .

$$
\eta=J_{\mathrm{sc}} V_{\mathrm{oc}} \frac{F F}{I_{0}}
$$

The DSC devices sensitized with D35 dye and employing $\left[\mathrm{Cu}(\mathrm{tmby})_{2}\right]^{2+/ 1+}$ reached $9.44 \%$ efficiency at AM $1.5 \mathrm{G}$ illumination. With the D35 dye, all the copper complexes showed remarkably high open circuit values above $1.0 \mathrm{~V}$ at full sunlight illumination. For $\left[\mathrm{Cu}(\mathrm{dmp})_{2}\right]^{2+/ 1+}$, the $V_{\text {oc }}$ was recorded as $1.14 \mathrm{~V}$ and is one of the highest values to our knowledge. Although the copper complexes have lower driving force for dye regeneration with respect to $\left[\mathrm{Co}(\mathrm{bpy})_{3}\right]^{3+/ 2+}$, the $J_{s c}$ values stayed similar. Especially in case of $\left[\mathrm{Cu}(\mathrm{tmby})_{2}\right]^{2+/ 1+}$, $J_{\text {sc }}$ reached up to $12.71 \mathrm{~mA} \mathrm{~cm}^{-2}$.

The D5 dye with a simple diphenylaniline moiety as electron donor and thiophene chain extending the $\pi$-conjugation lacks the steric-bulky structures to prevent the recombination of electrons from $\mathrm{TiO}_{2}$ with the electrolyte. A record efficiency for this dye of $7.5 \%$ was achieved with both $\left[\mathrm{Cu}(\mathrm{dmby})_{2}\right]^{2+/ 1+}$ and $\left[\mathrm{Cu}(\mathrm{dmp})_{2}\right]^{2+/ 1+}$ electrolytes. The $V_{\mathrm{oc}}$ values were 1.13 and $1.07 \mathrm{~V}$ for $\left[\mathrm{Cu}(\mathrm{dmp})_{2}\right]^{2+/ 1+}$ and $\left[\mathrm{Cu}(\mathrm{dmby})_{2}\right]^{2+/ 1+}$, respectively. These remarkable $V_{\text {oc }}$ values shows that the D5 dye can be effectively utilized as a co-sensitization dye for other systems. The molecular simplicity and compactness of this dye can allow better dye loading when it is applied in conjunction with bulkier dye molecules. In the case of $\left[\mathrm{Cu}(\mathrm{tmby})_{2}\right]^{2+/ 1+}$, the $J_{\mathrm{sc}}$ value was the highest as $10.3 \mathrm{~mA} \mathrm{~cm} \mathrm{~cm}^{-2}$, whereas the other electrolytes were above $9 \mathrm{~mA} \mathrm{~cm}^{-2}$. Depending on the smaller size of the D5 dye, the fill factors obtained with this chromophore were generally better.

$\left[\mathrm{Cu}(\text { tmby })_{2}\right]^{2+/ 1+}$ electrolyte with $\mathrm{D} 45$ dye ${ }^{46,47}$ reached a PCE value of $8.3 \%$. Although $\left[\mathrm{Cu}(\mathrm{dmby})_{2}\right]^{2+/ 1+}$ and $[\mathrm{Cu}-$ $\left.(\mathrm{dmp})_{2}\right]^{2+1}+$ electrolytes have limited driving force for regenerating the $\mathrm{D} 45$ dye, the PCE values were comparable to the one for $\left[\mathrm{Co}(\text { bpy })_{3}\right]^{3+/ 2+}$. For $\left[\mathrm{Cu}(\mathrm{dmby})_{2}\right]^{2+/ 1+}$ and $\left[\mathrm{Cu}(\mathrm{dmp})_{2}\right]^{2+/ 1+}$ species, the recombination suppressing parts of $\mathrm{D} 45$ ( $o, p$-dimetoxyphenyl units) can be considered as redundant when we compare it with the D5 dye.

In general, the FF values for $\left[\mathrm{Co}(\mathrm{bpy})_{3}\right]^{3+/ 2+}$ appeared to be higher than that of the copper complexes. This is attributed both to the higher charge transfer resistance of the counter electrode and the diffusion resistances for copper complexes, as reported by Kavan et al. ${ }^{32}$ The reason for the higher diffusion resistances of the $\mathrm{Cu}$ complexes was reported to be due to the coordination of TBP molecules to the copper complex molecular coordination sphere.

According to $J-V$ data, the $\left[\mathrm{Cu}(\mathrm{tmby})_{2}\right]^{2+/ 1+}$ and $[\mathrm{Cu}-$ (eto $\left.)_{2}\right]^{2+/ 1+}$ complexes correspond to similar current, voltage, and fill factor values for all of the sensitizers. This indicates that the ligand structures of these complexes do not cause a profound difference on photovoltaic performance. Instead, the driving force for dye regeneration and recombination is more important. 

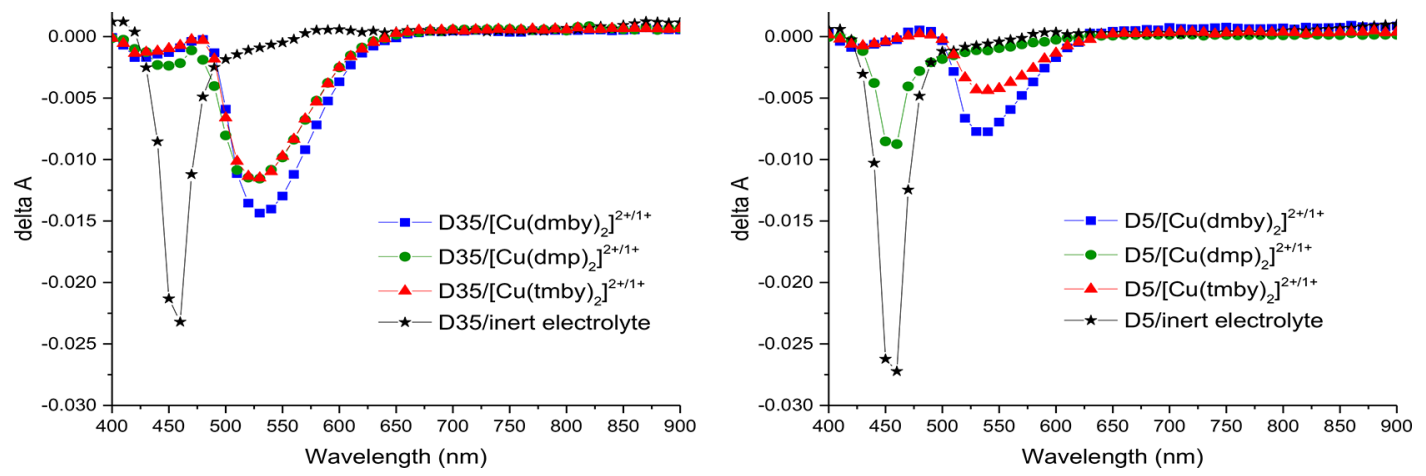

Figure 4. Photoinduced absorption spectroscopy spectra of D5- and D35-sensitized $\mathrm{TiO}_{2}$ films with the inert and the three copper complex electrolytes.

The typical IPCE spectra for D35 and D5 sensitizers employing copper electrolytes are given in Figure 3. For D35 dye, the maximum IPCE is found to be over $70 \%$ around 550 $\mathrm{nm}$, with the three copper compounds. The IPCE drop around $360 \mathrm{~nm}$ is attributed to the competitive light absorption of the FTO glass and the electrolyte. The slightly blue-shifted IPCE spectrum of the $\left[\mathrm{Cu}(\mathrm{dmp})_{2}\right]^{2+/ 1+}$ electrolyte indicates that this complex has a higher extinction coefficient compared with the other $\mathrm{Cu}$ complexes. In the case of D5-sensitized devices employing copper electrolytes, the maximum IPCE and the corresponding wavelength were observed to be higher than $70 \%$ (around $400 \mathrm{~nm}$ ). The parasitic light absorption was stronger around $500 \mathrm{~nm}$ when D5 dye was employed, which was attributed to the absorption of $\mathrm{Cu}(\mathrm{I})$ species.

Photoinduced Absorption Spectroscopy. The regeneration kinetics of D5 and D35 chromophores employing $\left[\mathrm{Cu}(\mathrm{tmby})_{2}\right]^{2+/ 1+},\left[\mathrm{Cu}(\mathrm{dmby})_{2}\right]^{2+/ 1+},\left[\mathrm{Cu}(\mathrm{dmp})_{2}\right]^{2+/ 1+}$, and inert electrolyte (0.1 M LiTFSI and 0.6 M TBP in acetonitrile) were investigated via photoinduced absorption spectroscopy measurements (see Figure 4). For both sensitizers, with the inert electrolyte, a bleach was observed around $460 \mathrm{~nm}$ indicating a ground state bleach of the dye upon oxidation. The absorption change of the dye molecules stems from the change of the electric field caused by photoinjected electrons, i.e., a Stark shift. ${ }^{48,49}$ In the presence of copper complexes, the bleach shifted to $520 \mathrm{~nm}$ (for the D5 sensitizer employing $\left[\mathrm{Cu}(\mathrm{dmp})_{2}\right]^{2+/ 1+}$, the bleach persisted around $460 \mathrm{~nm}$ due to excitation light) as a result of the Stark effect. The lack of absorption peaks of oxidized dye molecules in the photoinduced absorption spectroscopy spectra indicates that oxidized dye molecules are efficiently regenerated by the $\mathrm{Cu}(\mathrm{I})$ complex.

Transient Absorption Spectroscopy. Transient absorption spectroscopy measurements were carried out to investigate the dye regeneration kinetics and recombination of oxidized dye molecules and injected electrons in $\mathrm{TiO}_{2}$. The transient absorption spectroscopy figures and the corresponding data for the D5-, D35-, and D45-sensitized films employing $\left[\mathrm{Cu}(\mathrm{tmby})_{2}\right]^{2+/ 1+},\left[\mathrm{Cu}(\mathrm{dmby})_{2}\right]^{2+/ 1+},\left[\mathrm{Cu}(\mathrm{dmp})_{2}\right]^{2+/ 1+},[\mathrm{Cu}-$ (eto $\left.)_{2}\right]^{2+/ 1+}$, and the inert electrolyte are given in Figure 5 and Table 2, respectively. In the absence of redox couples, the recombination of injected electrons in $\mathrm{TiO}_{2}$ and oxidized dye molecules showed absorbance decay signals of 1.1, 2.3, and 1.9 ms half-times $\left(\tau_{1 / 2}\right)$, for D5, D35, and D45 dyes, respectively. These half-time values clearly show the effect of electron donating substituents on the chromophore. The $o, p$-dibutoxyphenyl substituent involved in the D35 dye provides the strongest barrier for recombination of injected electrons and oxidized dye molecules as observed by the highest half-time. D5 dye shows the shortest recombination half-time since it lacks the recombination preventing bulky units. The presence of copper species accelerates the absorbance signal decay which indicates faster regeneration of the oxidized dye molecules with $\mathrm{Cu}(\mathrm{I})$ species. The regeneration efficiencies $\left(\Phi_{\text {reg }}\right)$ are estimated via eq 2 . All the copper complexes showed $\Phi_{\text {reg }}$ values that are close to $100 \%$ with D5, D35, and D45 dyes.

$$
\frac{k_{\text {reg }}}{k_{\text {reg }}+k_{\text {rec }}}=1-\frac{\tau_{1 / 2, \text { redox }}}{\tau_{1 / 2, \text { inert }}}
$$

For D35 and D45 dyes, the $\tau_{1 / 2}$ values can be related to the driving force for dye regeneration, suggesting a Marcus normal regime for dye regeneration for the complexes under study. This finding will be supported by the DFT calculations described in detail further below. Thus, the $\left[\mathrm{Cu}(\mathrm{tmby})_{2}\right]^{2+/ 1+}$ and $\left[\mathrm{Cu}(\text { eto })_{2}\right]^{2+/ 1+}$ complexes showed the shortest regeneration times due to the more negative formal redox potential enabling higher driving forces for dye regeneration. In the case of the D5 dye no clear relation between regeneration half-times and driving force values was observable. The transient absorption spectroscopy measurements indicate that the copper redox mediators are able to regenerate oxidized dye molecules with faster kinetics in comparison to the on Cocomplexes based redox mediators. ${ }^{50}$

Electron Lifetime and Charge Extraction Measurements. The recombination kinetics were further investigated by a small amplitude light-modulation technique in terms of electron lifetime and charge extraction measurements. For the same light intensity, the measured electron lifetimes vs extracted charge values are given in Figure 6. We can clearly observe that the $\left[\mathrm{Co}(\mathrm{bpy})_{3}\right]^{3+/ 2+}$ electrolyte has relatively lower lifetimes in most devices, for the same extracted charge values, i.e., the same density of conduction band electrons. Only the D35 dye, employing the $\left[\mathrm{Cu}(\mathrm{dmp})_{2}\right]^{2+/ 1+}$ electrolyte, gives lower electron lifetimes compared to $\left[\mathrm{Co}(\mathrm{bpy})_{3}\right]^{3+/ 2+}$. For $\left[\mathrm{Cu}(\mathrm{dmp})_{2}\right]^{2+/ 1+}$ electrolyte, this behavior is attributed to the bimolecular reductive quenching of the excited dye by the $\left[\mathrm{Cu}(\mathrm{dmp})_{2}\right]^{2+}$ species as reported by Freitag et al. ${ }^{24}$ In this previous work, ${ }^{24}$ it was stated that the excited dye can be intercepted with an electron from the electrolyte, resulting in the reduced state of the dye. Furthermore, quenching of the reduced dye by the electrolyte competes with electron injection and results in a lower photocurrent. Therefore, the lower lifetime and charge extraction values for D35-sensitized 


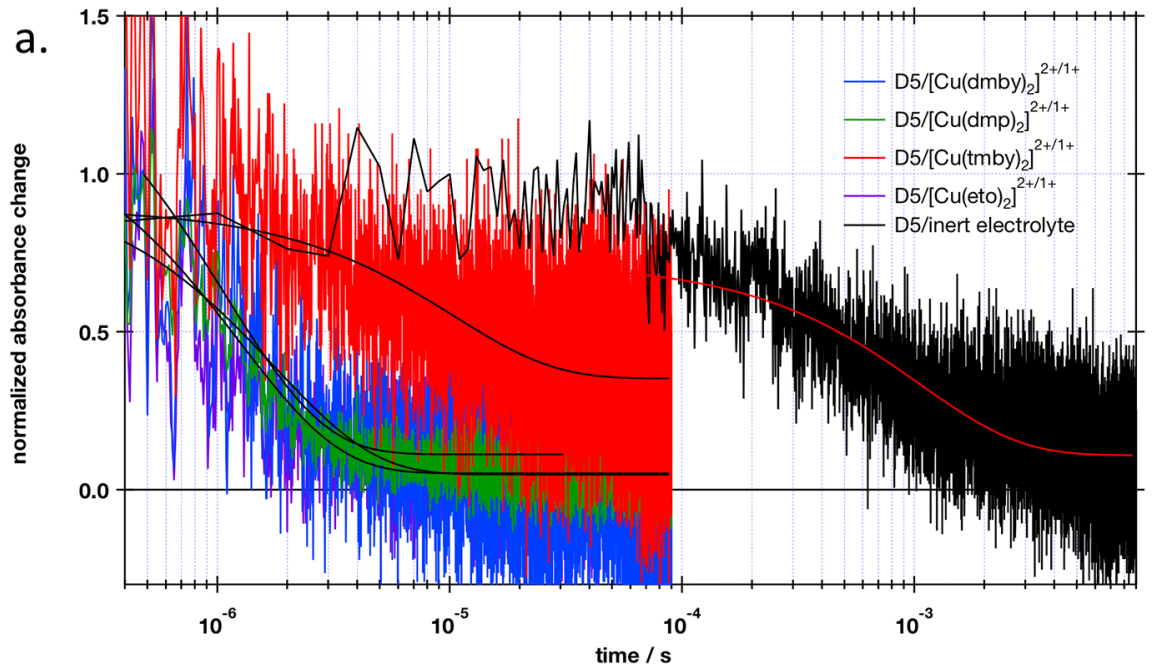

b.

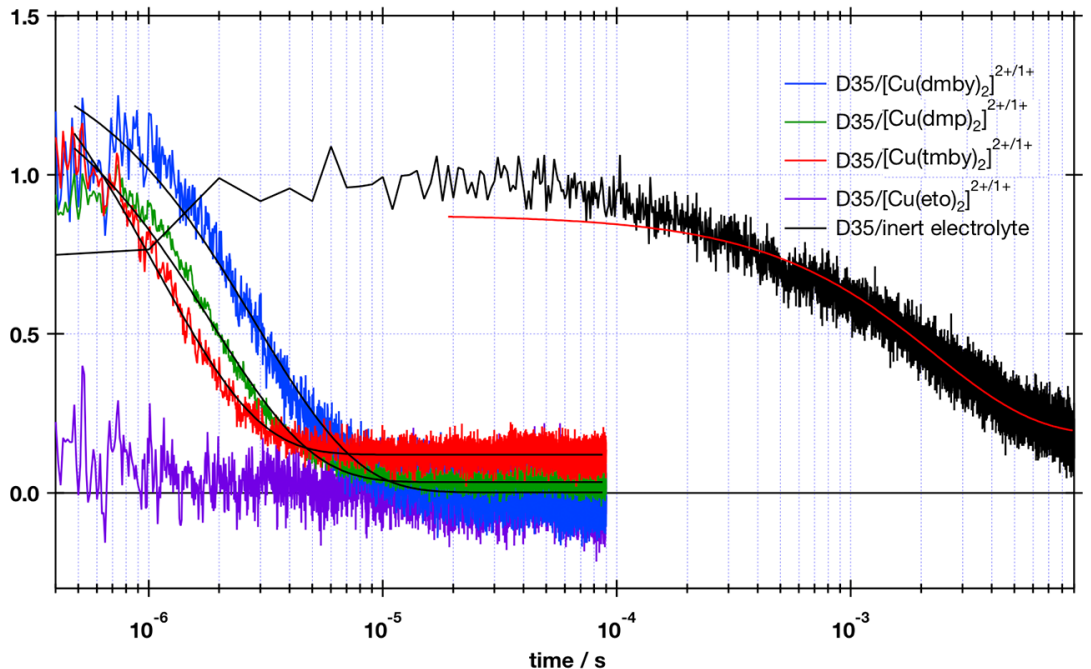

c.

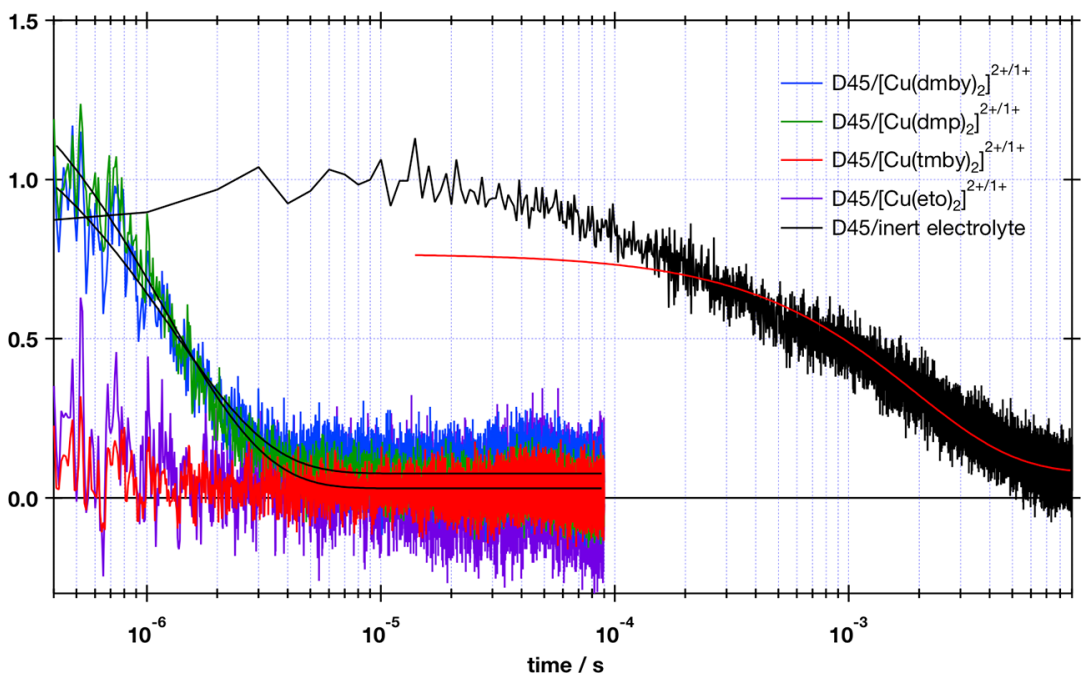

Figure 5. Transient absorption spectroscopy measurements of (a) D5-, (b) D35-, and (c) D45-sensitized $\mathrm{TiO}_{2}$ films with inert, $\left[\mathrm{Cu}(\mathrm{dmby})_{2}\right]^{2+/ 1+}$, $\left[\mathrm{Cu}(\mathrm{tmby})_{2}\right]^{2+/ 1+},\left[\mathrm{Cu}(\text { eto })_{2}\right]^{2+/ 1+}$, and $\left[\mathrm{Cu}(\mathrm{dmp})_{2}\right]^{2+/ 1+}$ electrolytes.

films, employing $\left[\mathrm{Cu}(\mathrm{dmp})_{2}\right]^{2+/ 1+}$, can also be explained by bimolecular reductive quenching by considering the same donating group of D35 and LEG4 dyes.

Electrochemical Impedance Spectroscopy. In order to disregard the effects of light on the analysis of recombination kinetics, i.e., eliminating the recombination losses to unregenerated or oxidized dyes, the dark currents, dark recombination resistances, and chemical capacitances are analyzed.

In Figure 7, the dark currents of DSC devices, are presented. As expected, with different dye and electrolyte employments, the dark current values change. These differences are related to the kinetics of electron transfer reactions at the $\mathrm{TiO}_{2} /$ dye/ electrolyte interface and $\mathrm{TiO}_{2}$ conduction band changes, which 
Table 2. Transient Absorption Spectroscopy Measurements Data (Halftime/Regeneration Efficiency) for the TiO $\mathrm{Films}_{2}$ Sensitized with D5, D35, and D45 Dyes Employing $\left[\mathrm{Cu}(\mathrm{tmby})_{2}\right]^{2+/ 1+},\left[\mathrm{Cu}(\mathrm{dmby})_{2}\right]^{2+/ 1+},\left[\mathrm{Cu}(\mathrm{dmp})_{2}\right]^{2+/ 1+}$, and $\left[\mathrm{Cu}(\mathrm{eto})_{2}\right]^{2+/ 1+}$

\begin{tabular}{|c|c|c|c|c|c|}
\hline & inert & {$\left[\mathrm{Cu}(\mathrm{dmby})_{2}\right]^{2+/ 1+}$} & {$\left[\mathrm{Cu}(\mathrm{dmp})_{2}\right]^{2+/+}$} & {$\left[\mathrm{Cu}(\mathrm{tmby})_{2}\right]^{2+/+}$} & {$\left[\mathrm{Cu}(\text { eto })_{2}\right]^{2+/+}$} \\
\hline D5 & $1.1 \mathrm{~ms}$ & $1.8 \mu \mathrm{s} / 99.8 \%$ & $1.2 \mu \mathrm{s} / 99.9 \%$ & $10.3 \mu \mathrm{s} / 99.0 \%$ & $1.1 \mu \mathrm{s} / 99.9 \%$ \\
\hline D35 & $2.3 \mathrm{~ms}$ & $2.9 \mu \mathrm{s} / 99.9 \%$ & $1.9 \mu \mathrm{s} / 99.9 \%$ & $1.1 \mu \mathrm{s} / 100 \%$ & $<1 \mu \mathrm{s} / 99.9 \%$ \\
\hline D45 & $1.9 \mathrm{~ms}$ & $1.3 \mu \mathrm{s} / 99.9 \%$ & $1.2 \mu \mathrm{s} / 99.9 \%$ & $<1 \mu \mathrm{s} / 99.9 \%$ & $<1 \mu \mathrm{s} / 99.9 \%$ \\
\hline
\end{tabular}
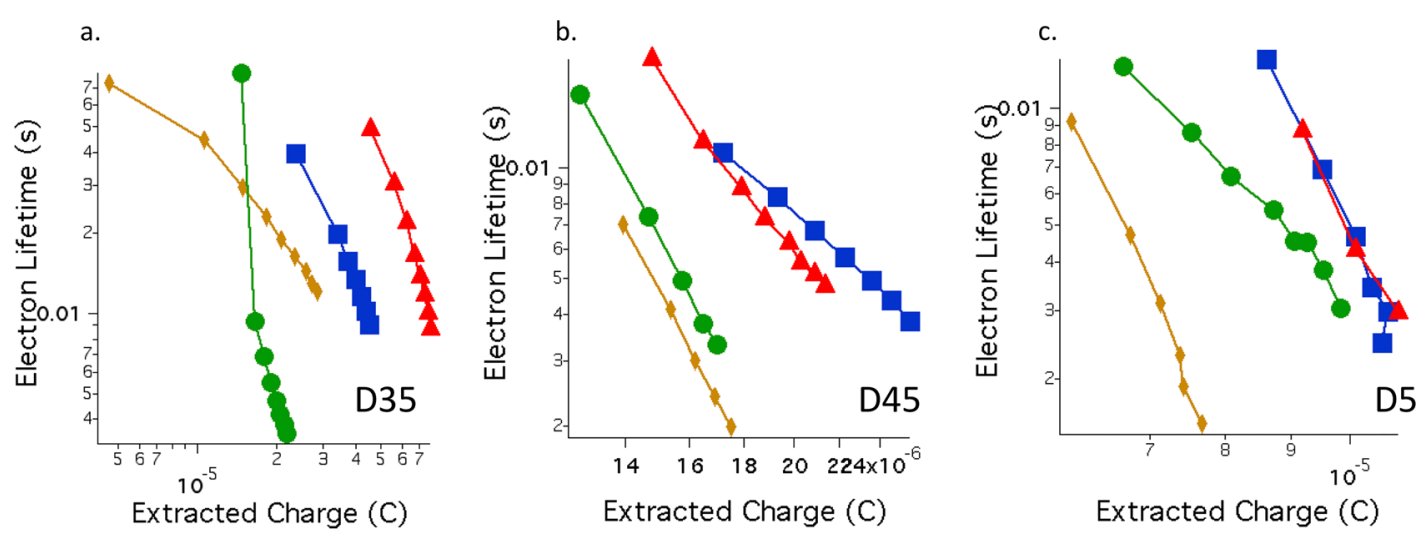

Figure 6. Electron lifetime vs charge extraction data obtained from the Toolbox measurements for (a) D35-, (b) D45-, and (c) D5-sensitized TiO 2 films $\left(\left[\mathrm{Cu}(\mathrm{dmby})_{2}\right]^{2+/ 1+}\right.$, blue squares; $\left[\mathrm{Cu}(\text { tmby })_{2}\right]^{2+/ 1+}$, red triangles; $\left[\mathrm{Cu}(\mathrm{dmp})_{2}\right]^{2+/ 1+}$, green circles; $\left[\mathrm{Co}(\mathrm{bpy})_{3}\right]^{3+/ 2+}$, yellow diamonds).
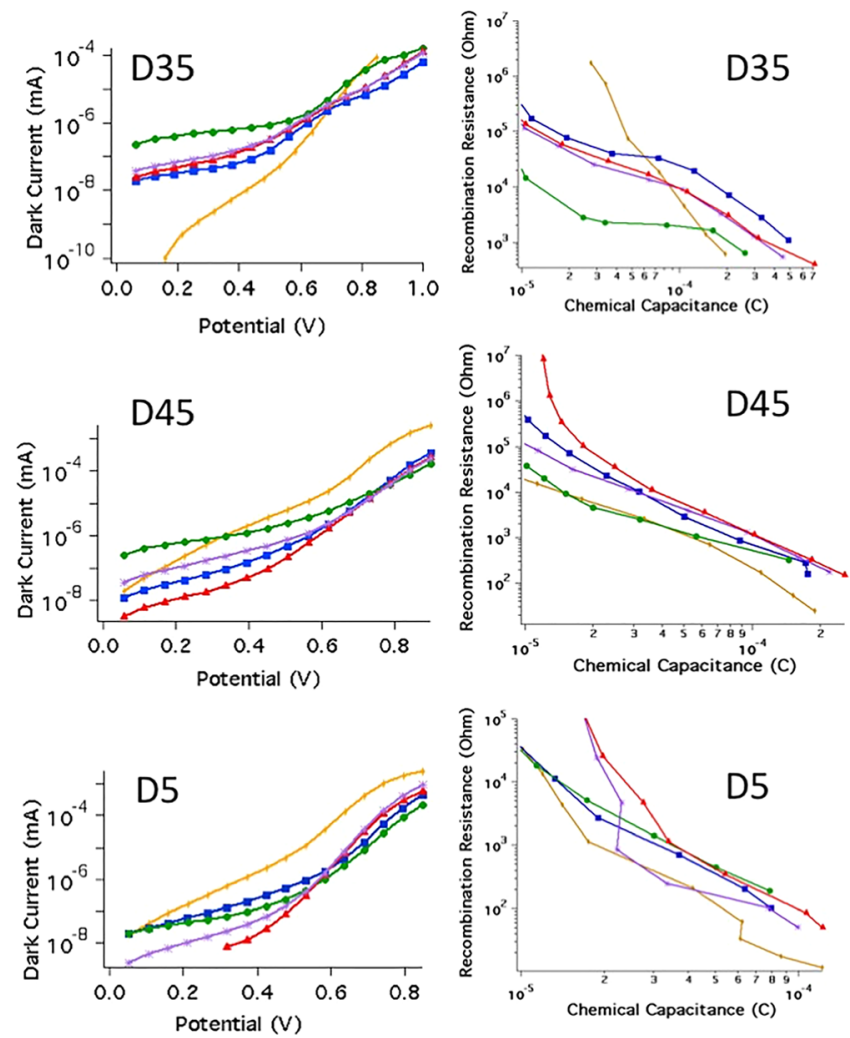

Figure 7. Dark currents, recombination resistance, and capacitance values obtained from the electrical impedance spectroscopy measurements $\left(\left[\mathrm{Cu}(\mathrm{dmby})_{2}\right]^{2+/ 1+}\right.$, blue squares; $\left[\mathrm{Cu}(\mathrm{tmby})_{2}\right]^{2+/ 1+}$, red triangles; $\left[\mathrm{Cu}(\text { eto })_{2}\right]^{2+/ 1+}$, purple stars; $\left[\mathrm{Cu}(\mathrm{dmp})_{2}\right]^{2+11+}$, green circles; $\left[\mathrm{Co}(\mathrm{bpy})_{3}\right]^{3+/ 2+}$, yellow diamonds).

are important for the recombination characteristics in the DSC devices. $^{51}$ The recombination resistance and chemical capacitance of $\mathrm{TiO}_{2}$ are extracted by using the transmission line model. ${ }^{37}$
For all the devices, the recombination resistance showed a decreasing trend with increasing capacitance at forward bias, as reflected in the curves of dark currents. (At low forward bias (up to $0.4 \mathrm{~V}$ ), the recombination resistance behavior is dominated by the recombination of electrons with FTO (fluorinated tin oxide); therefore, the data obtained at higher forward bias will provide a better charge transfer analysis ${ }^{37}$ ). By concentrating on the higher chemical capacitance data, we can see that the recombination resistance increases according to the steric substituents of the dyes, as expected. (e.g., at a chemical capacitance of $10^{-4} \mathrm{C}$, for $\left[\mathrm{Cu}(\mathrm{tmby})_{2}\right]^{2+/ 1+}$ electrolyte the recombination resistance is estimated approximately as $10^{3}, 3 \times 10^{3}$, and $5 \times 10^{4} \Omega$ for the D5, D45, and D35 dyes, respectively). For the three sensitizers, at the same capacitance the recombination resistances were the lowest and the dark currents were the highest for $\left[\mathrm{Co}(\mathrm{bpy})_{3}\right]^{3+/ 2+}$ indicating a higher rate of recombination between the electrons in $\mathrm{TiO}_{2}$ and $\mathrm{Co}(\mathrm{III})$ species.

$\left[\mathrm{Cu}(\mathrm{tmby})_{2}\right]^{2+/ 1+}$ and $\left[\mathrm{Cu}(\text { eto })_{2}\right]^{2+/ 1+}$ complexes showed almost the same recombination resistance values since they have similar formal redox potentials. This finding suggests that the structural differences with tmby and eto ligands have lower effect on reaction rates compared to differences in driving forces.

According to the Marcus-Gerischer model, the electron transfer rates depend on the driving force for reaction, electronic coupling, the reorganization energies, and diffusion rates of reactants. The rate constant for electron transfer $k_{\text {et }}$ can be given as

$$
k_{\text {et }}=\frac{{H_{A B}}^{2}}{\sqrt{4 \pi \lambda k_{\mathrm{B}} T}} \exp \left(-\frac{\left(\Delta G^{\circ}+\lambda\right)^{2}}{4 \lambda k_{\mathrm{B}} T}\right)
$$

where $H_{\mathrm{AB}}{ }^{2}$ is the electronic coupling, $\lambda$ is the reorganization energy, and $\Delta G^{\circ}$ is the reaction free energy. The measured electron lifetimes, extracted charge values, and recombination resistances qualitatively indicate a lower recombination rate for copper complexes compared to $\left[\mathrm{Co}(\mathrm{bpy})_{3}\right]^{3+/ 2+}$. In order to 
understand the origin of this trend, a more detailed analysis is provided below with rest potential measurements and density functional theory calculations.

Rest Potential Measurements. As discussed in our previous studies, ${ }^{28,32} \mathrm{Cu}$ (II) species exhibits more complicated cyclic voltammograms based upon counterion coordinations or base coordinations. We also showed that these more complicated copper(II) species show more negative redox potentials. ${ }^{28,31,32}$ In this study, we also carried out electrolyte rest potential measurements in order to see how $\mathrm{Cu}$ (II) species affects the electrolyte redox potential. Surprisingly, there was a significant difference between the rest potentials of electrolytes and cyclic voltammetry data of only $\mathrm{Cu}(\mathrm{I})$ species, as given in Table 3. With this finding we can speculate that penta-

Table 3. Rest Potentials of $\left[\mathrm{Cu}(\mathrm{tmby})_{2}\right]^{2+/ 1+}$, $\left[\mathrm{Cu}(\mathrm{dmp})_{2}\right]^{2+/ 1+}$, and $\left[\mathrm{Co}(\mathrm{bpy})_{3}\right]^{3+/ 2+}$ Electrolytes and Formal Redox Potentials of Copper(I) Species and $\left[\mathrm{Co}(\mathrm{bpy})_{3}\right]^{+2}$

\begin{tabular}{ccc} 
redox couple & $\begin{array}{c}\text { rest potential } \\
(\mathrm{V} \text { vs SHE })\end{array}$ & $\begin{array}{c}\text { formal redox potential } \\
(\mathrm{V} \text { vs SHE })\end{array}$ \\
{$\left[\mathrm{Cu}(\mathrm{tmby})_{2}\right]^{2+/ 1+}$} & 0.644 & $0.87^{28}$ \\
{$\left[\mathrm{Cu}(\mathrm{dmp})_{2}\right]^{2+/ 1+}$} & 0.669 & $0.93^{28}$ \\
{$\left[\mathrm{Co}(\mathrm{bpy})_{2}\right]^{3+/ 2+}$} & 0.525 & $0.56^{12}$ \\
\hline
\end{tabular}

coordinated $\mathrm{Cu}(\mathrm{II})$ species shifts the electrolyte potentials to more negative values. ${ }^{34,35}$ Since the driving force for recombination reaction is determined by the difference between the quasi-Fermi level of $\mathrm{TiO}_{2}$ and the redox potential of $\mathrm{Cu}(\mathrm{II})$ species, reaction free energies $\left(\Delta G^{\circ}\right.$ in eq 3$)$ for recombination are less than the values expected ${ }^{34}$ (i.e., when $\mathrm{Cu}(\mathrm{I})$ and $\mathrm{Cu}$ (II) species are assumed to have the same redox potentials). For $\left[\mathrm{Co}(\mathrm{bpy})_{3}\right]^{3+/ 2+}$, the difference between cyclic voltammetry and rest potential measurements can be considered insignificant in comparison to the data obtained with copper complexes.

Density Functional Theory Calculations. As observed in our previous studies, ${ }^{28,32}$ when we use $\mathrm{CuCl}_{2}$ as the starting material for $\mathrm{Cu}(\mathrm{II})$ production, the obtained $\mathrm{Cu}(\mathrm{II})$ species exhibits complicated electrochemical behaviors, unlike the electrochemically clean $\mathrm{Cu}(\mathrm{I})$ counterparts, because of counterion coordination. We also showed that, by using $\mathrm{Cu}(\mathrm{TFSI})_{2}$ as the starting material, electrochemically clean $\mathrm{Cu}$ (II) species can be produced. ${ }^{31}$ However, this clean $\mathrm{Cu}$ (II) species tends to adopt more complicated coordination spheres in the presence of TBP or other Lewis base additives and exhibits more negative redox potentials. ${ }^{28,31,32}$ Following these findings, the DFT computations are carried out for "with TBP" and "without TBP" cases.

First, in order to see the possible TBP interactions, the minimum-energy structures and binding free energies are calculated. In the absence of TBP, copper(I) species prefer a tetrahedral coordination sphere for copper. Upon oxidation, the tetrahedral alignment decays to a distorted tetragonal structure, and most favored square-planar $\mathrm{Cu}$ (II) coordination is prevented by the steric hindrance effects of the methyl groups adjacent to nitrogen atoms of the ligands. The minimum-energy structures of $\left[\mathrm{Cu}(\mathrm{tmby})_{2}\right]^{2+/ 1+}$ and $[\mathrm{Cu}-$ $\left.(\text { eto })_{2}\right]^{2+/ 1+}$, with and without TBP, are given in Figure 8 . Analogous minimum-energy structures for $\left[\mathrm{Cu}(\mathrm{dmby})_{2}\right]^{2+/ 1+}$ and $\left[\mathrm{Cu}(\mathrm{dmp})_{2}\right]^{2+/ 1+}$ are provided in Figure S5. Although, according to our calculations, TBP remains in the vicinity of both $\mathrm{Cu}(\mathrm{I})$ and $\mathrm{Cu}(\mathrm{II})$ complexes, computed binding free energy values $\left(\Delta G_{\text {bind }}\right)$ of TBP (Table 4$)$ are very different for

Table 4. Binding Free Energies $\left(\Delta G_{\text {bind }}\right)$ of TBP on $\left[\mathrm{CuL}_{2}\right]^{1+}$ and $\left[\mathrm{CuL}_{2}\right]^{2+}$

\begin{tabular}{lcc} 
& \multicolumn{2}{c}{$\Delta G_{\text {bind }}(\mathrm{TBP})(\mathrm{eV})$} \\
\cline { 2 - 3 } ligand & $\mathrm{Cu}^{\mathrm{I}}-\mathrm{L}_{2}$ & $\mathrm{Cu}^{\mathrm{II}}-\mathrm{L}_{2}$ \\
dmp & 0.393 & -0.334 \\
dmby & 0.350 & -0.360 \\
tmby & 0.329 & -0.265 \\
eto & 0.340 & -0.268
\end{tabular}

$\mathrm{Cu}(\mathrm{I})$ and $\mathrm{Cu}(\mathrm{II})$ species. Negative free energies correspond to favorable binding, with a clear indication of TBP coordination to $\mathrm{Cu}(\mathrm{II})$. On the other hand, positive values correspond to an unfavorable interaction between the $\mathrm{Cu}(\mathrm{I})$
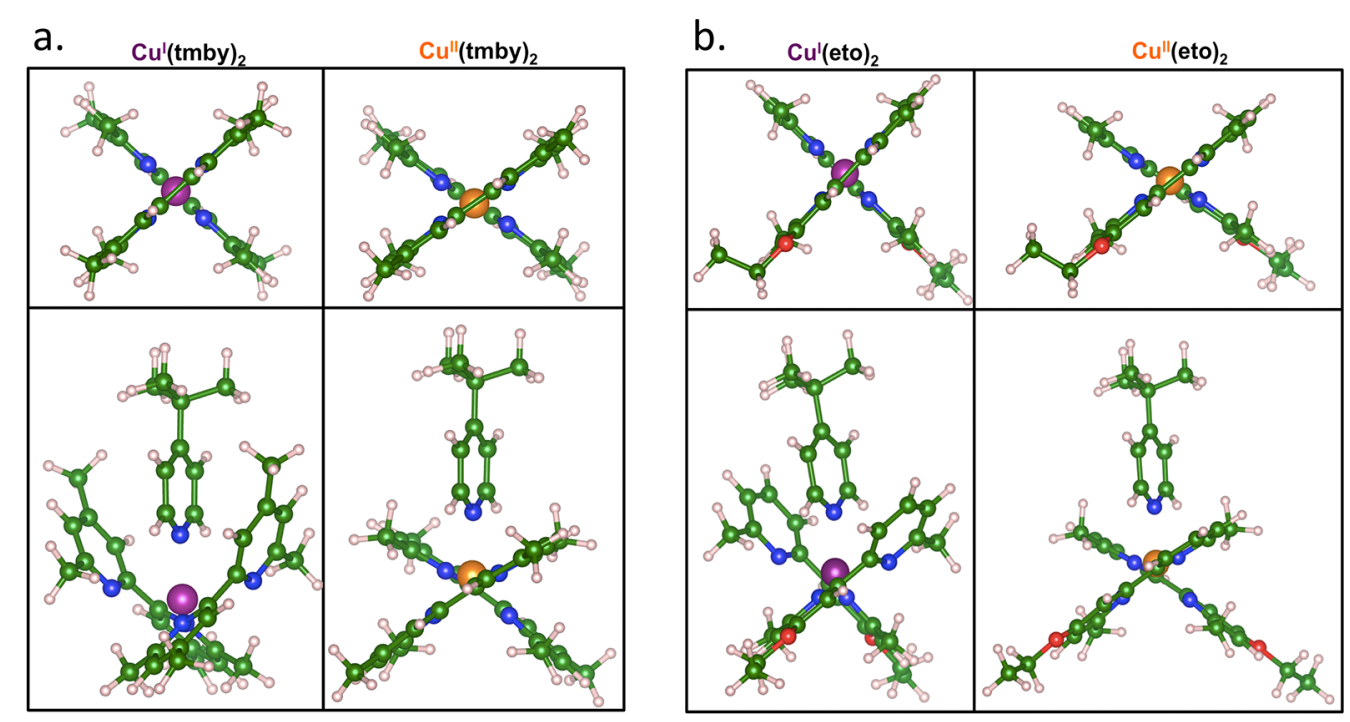

Figure 8. (a) $\left[\mathrm{Cu}(\text { tmby })_{2}\right]^{1+}$ (left) and $\left[\mathrm{Cu}(\text { tmby })_{2}\right]^{2+}$ (right) and (b) $\left[\mathrm{Cu}(\text { eto })_{2}\right]^{1+}$ (left) and $\left[\mathrm{Cu}(\text { eto })_{2}\right]^{2+}$ (right) minimum-energy structures without and with TBP (top and bottom, respectively) calculated at the DFT-B3LYP-D3BJ level of theory in acetonitrile (PCM). 
Table 5. Free Energy Differences $\left(\Delta G_{\mathrm{OX}} \mathrm{Cu}^{\mathrm{I}} / \mathrm{Cu}^{\mathrm{II}}\right)$ for the $\mathrm{Cu}(\mathrm{I}) \rightarrow \mathrm{Cu}(\mathrm{II})$ Process for Complexes without $\mathrm{TBP}\left(\left[\mathrm{CuL}_{2}\right]^{1+} /\right.$ $\left.\left[\mathrm{CuL}_{2}\right]^{2+}\right)$, with Both $\left[\mathrm{CuL}_{2}\right]^{1+}$ and $\left[\mathrm{CuL}_{2}\right]^{2+}$ Coordinated with TBP $\left(\left[\mathrm{CuL}_{2}-\mathrm{TBP}\right]^{1+} /\left[\mathrm{CuL}_{2}-\mathrm{TBP}\right]^{2+}\right)$ and with Only $\left[\mathrm{CuL}_{2}\right]^{2+}$ Coordinated by TBP $\left(\left[\mathrm{CuL}_{2}\right]^{1+} /\left[\mathrm{CuL}_{2}-\mathrm{TBP}\right]^{2+}\right)$

\begin{tabular}{lccc} 
& \multicolumn{3}{c}{$\Delta G_{\mathrm{OX}}\left(\mathrm{Cu}^{\mathrm{I}} / \mathrm{Cu}{ }^{\mathrm{II}}\right)(\mathrm{eV})$} \\
\cline { 2 - 4 } ligand & {$\left[\mathrm{CuL}_{2}\right]^{1+} /\left[\mathrm{CuL}_{2}\right]^{2+}$} & {$\left[\mathrm{CuL}_{2}-\mathrm{TBP}\right]^{1+} /\left[\mathrm{CuL}_{2}-\mathrm{TBP}^{2+}\right.$} & 4.86 \\
dmp & 5.19 & 4.54 & 4.89 \\
dmby & 5.25 & 4.52 & 4.85 \\
tmby & 5.12 & 4.49 & 4.83 \\
eto & 5.10 &
\end{tabular}

complexes and TBP. Thus, we can conclude that TBP binds selectively to $\mathrm{Cu}$ (II) in the reaction media.

The charge transfer process between the photo-oxidized dye $\left(\mathrm{D}^{+}\right)$and the electrolyte that leads to dye regeneration is in competition with the charge recombination process that occurs at the solid-liquid interface between the electron in the $\mathrm{TiO}_{2}$ conduction band and the electrolyte. The $\mathrm{Cu}^{2+} / \mathrm{Cu}^{1+}$ - and $\mathrm{Co}^{3+} / \mathrm{Co}^{2+}$-complex redox couples are involved in the dynamic equilibrium between the dye regeneration and charge recombination reactions. To address the energetics in play in these processes, we also computed the redox potentials and the total reorganization energies for the four copper based complexes with dmp, dmby, tmby, and eto ligands by considering the complexes without TBP $\left(\left[\mathrm{CuL}_{2}\right]^{2+} /\right.$ $\left.\left[\mathrm{CuL}_{2}\right]^{1+}\right)$, with both $\left[\mathrm{CuL}_{2}\right]^{2+}$ and $\left[\mathrm{CuL}_{2}\right]^{1+}$ coordinated with TBP $\left(\left[\mathrm{CuL}_{2}-\mathrm{TBP}\right]^{2+} /\left[\mathrm{CuL}_{2}-\mathrm{TBP}\right]^{1+}\right)$ and with only $\left[\mathrm{CuL}_{2}\right]^{2+}$ coordinated by TBP. The trends on computed redox potentials given in Table 5 are in good agreement with the experimental data, and the decreasing free energy values with TBP coordination also confirm our previous experimental findings. ${ }^{28,31,32}$

We must note here that absolute values of computed redox potentials are $0.2-0.5 \mathrm{eV}$ off the experimental values, as reported for similar DFT based approaches, ${ }^{52}$ due to the wellknown drawbacks of the approximated nature of the exchange-correlation term when comparing systems with a different number of electrons. Still, DFT can reliably predict reorganization energies $(\lambda)$, since they are calculated as energy differences between two points of the same potential energy surface. Table 6 reports the computed $\lambda$ values for all the complexes in both dye regeneration (DR) and charge recombination $(\mathrm{CR})$ directions, by considering the complexes without TBP, with both $\left[\mathrm{CuL}_{2}\right]^{1+}$ and $\left[\mathrm{CuL}_{2}\right]^{2+}$ coordinated

Table 6. Reorganization Energies $(\lambda)$ for the $\mathrm{Cu}(\mathrm{I}) \rightarrow$ $\mathrm{Cu}$ (II) Process for Complexes without TBP $\left(\left[\mathrm{CuL}_{2}\right]^{1+} /\right.$ $\left.\left[\mathrm{CuL}_{2}\right]^{2+}\right)$, with Both $\left[\mathrm{CuL}_{2}\right]^{1+}$ and $\left[\mathrm{CuL}_{2}\right]^{2+}$ Coordinated with TBP $\left(\left[\mathrm{CuL}_{2}-\mathrm{TBP}\right]^{1+} /\left[\mathrm{CuL}_{2}-\mathrm{TBP}\right]^{2+}\right)$ and with Only $\left[\mathrm{CuL}_{2}\right]^{2+}$ Coordinated by TBP $\left(\left[\mathrm{CuL}_{2}\right]^{1+} /\left[\mathrm{CuL}_{2}-\mathrm{TBP}\right]^{2+}\right)$ ( $\lambda$ for Dye Regeneration (DR) and Charge Recombination (CR) Indicated)

\begin{tabular}{|c|c|c|c|c|c|c|}
\hline \multirow[b]{3}{*}{ ligand } & \multicolumn{6}{|c|}{$\lambda(\mathrm{eV})$} \\
\hline & \multicolumn{2}{|c|}{$\left[\mathrm{CuL}_{2}\right]^{1+} /\left[\mathrm{CuL}_{2}\right]^{2+}$} & \multicolumn{2}{|c|}{$\begin{array}{c}{\left[\mathrm{CuL}_{2}-\right.} \\
\mathrm{TBP}^{1+} /\left[\mathrm{CuL}_{2}-\right. \\
\mathrm{TBP}]^{2+}\end{array}$} & \multicolumn{2}{|c|}{$\begin{array}{c}{\left[\mathrm{CuL}_{2}\right]^{1+} /\left[\mathrm{CuL}_{2}-\right.} \\
\text { TBP }]^{2+}\end{array}$} \\
\hline & $\mathrm{DR}$ & CR & DR & CR & $\mathrm{DR}$ & CR \\
\hline $\mathrm{dmp}$ & 0.321 & 0.368 & 0.391 & 0.754 & 0.272 & 1.368 \\
\hline dmby & 0.313 & 0.334 & 0.523 & 1.269 & 0.369 & 1.253 \\
\hline tmby & 0.322 & 0.350 & 0.595 & 1.203 & 0.380 & 1.232 \\
\hline eto & 0.317 & 0.362 & 0.542 & 1.182 & 0.328 & 1.268 \\
\hline
\end{tabular}

with TBP, and with only $\left[\mathrm{CuL}_{2}\right]^{2+}$ coordinated by TBP. For comparison, the reorganization energies for $\mathrm{DR}$ and $\mathrm{CR}$ of $\left[\mathrm{Co}(\text { bpy })_{3}\right]^{3+/ 2+}$ complex are also calculated as 0.656 and 0.761 $\mathrm{eV}$, respectively. We considered here only the low spin case for the cobalt complex that is most convenient for the DR process even if it is not the most stable in acetonitrile solution. ${ }^{52}$ Since the electrochemical behavior of $\left[\mathrm{Co}(\mathrm{bpy})_{3}\right]^{3+/ 2+}$ is invariant with the TBP addition, ${ }^{32}$ the reorganization energies are calculated for solely $\mathrm{Co}^{2+} \rightarrow \mathrm{Co}^{3+}$ and $\mathrm{Co}^{3+} \rightarrow \mathrm{Co}^{2+}$ reactions.

The total $\lambda_{\mathrm{DR}}$ values are not very different from just the internal reorganization energies, ${ }^{28}$ meaning that the solvent effects on this parameter are less relevant than the internal structural rearrangements upon oxidation of the transition metal center. In the absence of TBP (Table 6, $\left[\mathrm{CuL}_{2}\right]^{1+}$ / $\left[\mathrm{CuL}_{2}\right]^{2+}$ entries), with the reduction of the transition metal center, the $\lambda_{\mathrm{CR}}$ values are similar but slightly higher than the DR counterparts. The relative magnitudes of the reorganization energies for $\mathrm{CR}$ among $\mathrm{Cu}$ complexes and [Co(bpy $\left.)_{3}\right]^{3+/ 2+}$ have the same trend as that for DR: in the absence of TBP, all the copper complexes have lower reorganization energies $\left(\lambda_{\mathrm{CR}}\right)$ than the cobalt one. Considering coordination of TBP exclusively to $\mathrm{Cu}$ (II) (Table $6,\left[\mathrm{CuL}_{2}\right]^{1+}$ / $\left[\mathrm{CuL}_{2}-\mathrm{TBP}\right]^{2+}$ entries), $\lambda_{\mathrm{DR}}$ do not change dramatically, due to the geometry of $\left[\mathrm{CuL}_{2}\right]^{2+}$ species changing very little upon binding with TBP, and remain in the $0.3 \mathrm{eV}$ range, but $\lambda_{\mathrm{CR}}$ increase for all complexes to values higher than $1.2 \mathrm{eV}$.

Considering the unfavorable binding of TBP with $\mathrm{Cu}(\mathrm{I})$, we can further analyze the dye regeneration patterns without considering TBP. Table 7 reports the electronic features of D5

Table 7. Computed Electronic Properties of D5 and D45 Dyes: Absorption Maximum $\left(\lambda_{\max }\right)$ with Corresponding Oscillator Strength in Parentheses; Energy Difference between $S_{1}$ and $S_{0}$ Minima $\left(E_{0-0}\right)$; Internal $\left(\lambda_{\text {int }}\right)$ and External $\left(\lambda_{\text {ext }}\right)$ Reorganization Energies Computed for the Dye Regeneration Process $\left(\mathrm{D}^{+} \rightarrow \mathrm{D}\right)$

$\begin{array}{lcccc} & \text { abs }(\mathrm{nm})\left(\lambda_{\max }\right) & E_{0-0}(\mathrm{eV}) & \lambda_{\text {int }}(\mathrm{eV}) & \lambda_{\text {ext }}(\mathrm{eV}) \\ \text { D5 } & 497(1.929), \exp 476^{53} & 1.866 & 0.071 & 0.661 \\ \text { D45 } & 459(1.532), \exp 420^{54} & 2.102 & 0.261 & 0.591\end{array}$

and D45 dyes, including the internal and external reorganization energies. The predicted values on electronic properties are consistent with experimental counterparts. It is worth noting that the internal reorganization energies of the dyes are very small compared to the external one. This feature is consistent with the significant electronic rearrangement in these pushpull dyes, which has a more pronounced effect on the solvent than in the case of the electrolytes, where the charge center does not change position and is protected by the ligands.

From these data, by combining the experimental redox potentials and the DFT reorganization energies, we can derive 
Table 8. Marcus Parameters (Equation 4) for Dye Regeneration ( $\Delta G_{0}$ Values Are Derived from Experiments, Reorganization Energies Are from DFT calculations, All the Values Are in eV)

\begin{tabular}{|c|c|c|c|c|c|c|}
\hline & \multicolumn{3}{|c|}{ D5 } & \multicolumn{3}{|c|}{ D45 } \\
\hline & $\Delta G_{0}$ & $\lambda_{\text {tot }}$ & $\Delta G_{\mathrm{DR}}^{\#}$ & $\Delta G_{0}$ & $\lambda_{\text {tot }}$ & $\Delta G^{\#}$ \\
\hline$\left[\mathrm{Cu}(\mathrm{dmp})_{2}\right]^{1+}$ & -0.15 & 1.054 & 0.19 & -0.06 & 1.173 & 0.26 \\
\hline$\left[\mathrm{Cu}(\mathrm{dmby})_{2}\right]^{1+}$ & -0.11 & 1.046 & 0.21 & -0.02 & 1.165 & 0.28 \\
\hline$\left[\mathrm{Cu}(\mathrm{tmby})_{2}\right]^{1+}$ & -0.21 & 1.055 & 0.17 & -0.12 & 1.174 & 0.24 \\
\hline$\left[\mathrm{Cu}(\text { eto })_{2}\right]^{1+}$ & -0.22 & 1.050 & 0.16 & -0.13 & 1.169 & 0.23 \\
\hline$\left[\mathrm{Co}(\mathrm{bpy})_{3}\right]^{2+}(\mathrm{LS})$ & -0.52 & 1.388 & 0.14 & -0.43 & 1.508 & 0.19 \\
\hline
\end{tabular}

an approximate estimate of the activation energy in the Marcus model for the dye-electrolyte charge transfer (eq 4). Table 8 lists the computed parameters.

$$
\Delta G^{\#}=\frac{\left(\Delta G_{0}+\lambda\right)^{2}}{4 \lambda}
$$

The cobalt complex has a higher driving force for dye regeneration $\left(\Delta G^{\circ}\right)$ but also higher reorganization energy $\left(\lambda_{\text {tot }}\right)$ than the copper counterparts. The overall effect is that the activation energies $\left(\Delta G^{\#}\right)$ for $\mathrm{Cu}$ complexes and $\left[\mathrm{Co}(\mathrm{bpy})_{3}\right]^{3+/ 2+}$ are similar, the cobalt complex being only slightly favored and the $\left[\mathrm{Cu}(\text { eto })_{2}\right]^{2+/ 1+}$ having the lowest activation energy among the four tested ligands. Experimentally, the regeneration kinetics is slower for the [Co$\left.(\text { bpy })_{3}\right]^{3+/ 2+}$ complex $\left(\tau_{1 / 2}\right.$ of about $\left.8 \mu \mathrm{s},{ }^{53}\right)$ indicating steric hindrance and/or inclusion of high spin effects.

We focus now on the charge recombination as a competitive process of the dye regeneration, which undermines the photocurrent generation by recombining the hole at the electrolyte (the oxidized redox species) with the injected electron from the excited dye to the electrode conduction band (CB). In order to have a qualitative description of the charge recombination energetics and recalling the Marcus parameters, we must consider the reduction of the $\mathrm{Cu}^{2+}\left(\right.$ or $\mathrm{Co}^{3+}$ ) transition metal center by the electron that is coming from the $\mathrm{TiO}_{2} \mathrm{CB}$, neglecting the reorganization energy of the solid surface. Table 9 lists the computed results, following an approach similar to that in the dye regeneration case (without TBP).

Table 9. Marcus Parameter (Equation 2) for the Charge Recombination Process from the $\mathrm{CB}$ of $\mathrm{TiO}_{2}$ (Approximated at $-4 \mathrm{eV}^{55}$ ) to the Electrolyte in the Absence of TBP (All Values, eV)

\begin{tabular}{lccc} 
& $\Delta G_{0}$ & $\lambda_{\text {tot }}$ & $\Delta G_{\mathrm{CR}}^{\#}$ \\
{$\left[\mathrm{Cu}(\mathrm{dmp})_{2}\right]^{2+}$} & -1.37 & 0.31 & 0.92 \\
{$\left[\mathrm{Cu}(\mathrm{dmby})_{2}\right]^{2+}$} & -1.41 & 0.32 & 0.93 \\
{$\left[\mathrm{Cu}(\mathrm{tmby})_{2}\right]^{2+}$} & -1.31 & 0.34 & 0.69 \\
{$\left[\mathrm{Cu}(\text { eto })_{2}\right]^{2+}$} & -1.30 & 0.33 & 0.73 \\
& & & \\
{$\left[\mathrm{Co}(\mathrm{bpy})_{3}\right]^{3+}(\mathrm{LS})$} & -1.00 & 0.76 & 0.02 \\
\hline
\end{tabular}

These results outline a very different behavior between copper and cobalt when TBP is not considered. The copper complexes have a large driving force for $\mathrm{CR}$ and a small recombination energy, leading to an inverse Marcus regime $\left(\left|\Delta G^{\circ}\right| \gg \lambda_{\text {tot }}\right)$, and the resulting CR activation energy is two to three times larger than the DR values for all the complexes. On the contrary, a lower driving force and a higher reorganization energy for $\left[\mathrm{Co}(\mathrm{bpy})_{3}\right]^{3+/ 2+}\left(\left|\Delta G^{\circ}\right| \sim \lambda_{\text {tot }}\right)$ keeps the electron transfer recombination process kinetically favorable with a very low activation energy. Instead, if TBP interaction with $\mathrm{Cu}$ (II) species is considered, this results in much higher reorganization energies for the charge recombination process, and the electron transfer reaction stays in the Marcus normal regime (Table 6). For copper complexes, the higher reorganization energy values for charge recombination results in lower recombination rates. Moreover, considering the $\mathrm{Cu}(\mathrm{II})$ and TBP affinity, it is predicted that there will be less amount of TBP adsorbed on $\mathrm{TiO}_{2}$ films in the case of copper based electrolytes, which will shift the $\mathrm{TiO}_{2}$ conduction band position to more positive values, causing lower photovoltages. In a qualitative way, our results highlight a clear trend that is consistent and explains the observed behaviors for all the investigated electrolyte couples.

\section{CONCLUSIONS}

In this study, we showed the importance of the coordination sphere of copper redox mediators for dye regeneration and recombination processes. To minimize the dye regeneration overpotentials, the driving forces for dye regeneration are minimized. Transient absorption spectroscopy measurements show that the dye regeneration efficiencies stay close to unity with the D5, D35, and D45 dyes. Employing the common electrolyte additive, TBP, alters the molecular configurations especially by binding to $\mathrm{Cu}$ (II) species. These characteristics show some major differences for the reorganization energies and redox potentials of the corresponding $\mathrm{Cu}(\mathrm{II})$ species. Without TBP coordination, with higher driving forces for recombination, the recombination reaction rate constant becomes lower due to the lower reorganization energy values (i.e., $0.33-0.37 \mathrm{eV}$ ) of the complexes and the charge recombination process occurs in the Marcus inverted regime. However, with TBP coordination, the reorganization energies become higher (1.230-1.370 eV), the driving force for recombination becomes less, and the charge recombination occurs in Marcus normal regime. In comparison to $[\mathrm{Co}-$ $\left.(\text { bpy })_{3}\right]^{3+/ 2+}$ electrolyte, the device recombination resistances and lifetimes are observed to be higher with the copper complexes. Moreover, the effect of dye structure is observed to be less significant for the copper electrolytes. Even with the simple D5 dye, which lacks recombination preventing bulky units, remarkable $V_{\text {oc }}$ values of, e.g., $1.13 \mathrm{~V}$ can be achieved. A record $V_{\text {oc }}$ value of $1.14 \mathrm{~V}$ is achieved with the devices employing the D35 dye and $\left[\mathrm{Cu}(\mathrm{dmp})_{2}\right]^{2+/ 1+}$ electrolyte. Besides the obtained remarkable photovoltaic performances, this study provides a better understanding of copper redox mediators and can motivate the future DSC research in terms of improving photovoltage outputs by employing copper complexes. New ligand structures allowing dye regeneration with smaller driving forces, and recombination in Marcus 
inverted regime, could result in higher photovoltage outputs and accordingly improved device efficiencies. As another approach, TBP usage could be discarded by applying novel surface treatment techniques.

\section{ASSOCIATED CONTENT}

\section{S Supporting Information}

The Supporting Information is available free of charge on the ACS Publications website at DOI: 10.1021/acsaem.8b00957.

Synthetic procedures and characterization $\left({ }^{1} \mathrm{H} \mathrm{NMR}\right.$, ${ }^{13} \mathrm{C} \mathrm{NMR}$, and mass spectra), cyclic voltammetry, UVvis spectra, and minimum-energy structures (PDF)

\section{AUTHOR INFORMATION}

\section{Corresponding Authors}

*(A.H.) E-mail: anders.hagfeldt@epfl.ch.

*(M.F.) E-mail: marina.freitag@kemi.uu.se.

*(A.B.M.-G.) E-mail:anabelen.munozgarcia@unina.it.

ORCID $\odot$

Michele Pavone: 0000-0001-7549-631X

Gerrit Boschloo: 0000-0002-8249-1469

Jacques-E. Moser: 0000-0003-0747-4666

Michael Grätzel: 0000-0002-0068-0195

Marina Freitag: 0000-0002-4954-6851

Notes

The authors declare no competing financial interest.

\section{ACKNOWLEDGMENTS}

We acknowledge the Swiss National Science Foundation for financial support with the project entitled as "Fundamental studies of dye-sensitized and perovskite solar cells" with Project No. 200020_169695.

\section{REFERENCES}

(1) Green, M. A.; Hishikawa, Y.; Warta, W.; Dunlop, E. D.; Levi, D. H.; Hohl-Ebinger, J.; Ho-Baillie, A. W. H. Solar Cell Efficiency Tables (version 50). Prog. Photovoltaics 2017, 25, 668-676.

(2) Green, M. A.; Bremner, S. P. Energy Conversion Approaches and Materials for High-efficiency Photovoltaics. Nat. Mater. 2017, 16, 23-34.

(3) O’Regan, B.; Gratzel, M. A Low-cost, High-efficiency Solar Cell Based on Dye-sensitized Colloidal TiO2 Films. Nature 1991, 353, 737-740.

(4) Hagfeldt, A.; Boschloo, G.; Sun, L.; Kloo, L.; Pettersson, H. Dyesensitized solar cells. Chem. Rev. 2010, 110, 6595-6663.

(5) Cao, Y.; Liu, Y.; Zakeeruddin, S. M.; Hagfeldt, A.; Grätzel, M. Direct Contact of Selective Charge Extraction Layers Enables HighEfficiency Molecular Photovoltaics. Joule 2018, 2, 1108-1117.

(6) Barea, E. M.; Ortiz, J.; Paya, F. J.; Fernandez-Lazaro, F.; Fabregat-Santiago, F.; Sastre-Santos, A.; Bisquert, J. Energetic Factors Governing Injection, Regeneration and Recombination in Dye Solar Cells with Phthalocyanine Sensitizers. Energy Environ. Sci. 2010, 3, 1985-1194.

(7) Boschloo, G.; Hagfeldt, A. Characteristics of the Iodide/ Triiodide Redox Mediator in Dye-Sensitized Solar Cells. Acc. Chem. Res. 2009, 42, 1819-1826.

(8) Tian, H.; Sun, L. Iodine-free Redox Couples for Dye-sensitized Solar cells. J. Mater. Chem. 2011, 21, 10592-10601.

(9) Sapp, S. A.; Elliott, C. M.; Contado, C.; Caramori, S.; Bignozzi, C. A. Substituted Polypyridine Complexes of Cobalt(II/III) as Efficient Electron-Transfer Mediators in Dye-sensitized Solar Cells. J. Am. Chem. Soc. 2002, 124, 11215-11222.

(10) Feldt, S. M.; Lohse, P. W.; Kessler, F.; Nazeeruddin, M. K.; Gratzel, M.; Boschloo, G.; Hagfeldt, A. Regeneration and Recombi- nation Kinetics in Cobalt Polypyridine Based Dye-sensitized Solar Cell, Explained Using Marcus Theory. Phys. Chem. Chem. Phys. 2013, 15, 7087-7097.

(11) Feldt, S. M.; Wang, G.; Boschloo, G.; Hagfeldt, A. Effects of Driving Forces for Recombination and Regeneration on the Photovoltaic Performance of Dye-sensitized Solar Cells Using Cobalt Polypyridine Redox Couples. J. Phys. Chem. C 2011, 115, 2150021507.

(12) Feldt, S. M.; Gibson, E. A.; Gabrielsson, E.; Sun, L.; Boschloo, G.; Hagfeldt, A. Design of Organic Dyes and Cobalt Polypyridine Redox Mediators for High-efficiency Dye-sensitized Solar Cells. J. Am. Chem. Soc. 2010, 132, 16714-16724.

(13) Williams, V. O.; Jeong, N. C.; Prasittichai, C.; Farha, O. K.; Pellin, M. J.; Hupp, J. T. Fast Transporting ZnO-TiO2 Coaxial Photoanodes for Dye-Sensitized Solar Cells Based on ALD-Modified $\mathrm{SiO} 2$ Aerogel Frameworks. ACS Nano 2012, 6, 6185-6196.

(14) Klahr, B. M.; Hamann, T. W. Performance Enhancement and Limitations of Cobalt Bipyridyl Redox Shuttles in Dye-Sensitized Solar Cells. J. Phys. Chem. C 2009, 113, 14040-14045.

(15) Jiang, X.; Marinado, T.; Gabrielsson, E.; Hagberg, D. P.; Sun, L.; Hagfeldt, A. Structural Modification of Organic Dyes for Efficient Coadsorbent-Free Dye-Sensitized Solar Cells. J. Phys. Chem. C 2010, 114, 2799-2805.

(16) Marinado, T.; Nonomura, K.; Nissfolk, J.; Karlsson, M. K.; Hagberg, D. P.; Sun, L.; Mori, S.; Hagfeldt, A. How the Nature of Triphenylamine-Polyene Dyes in Dye-Sensitized Solar Cells Affects the Open-Circuit Voltage and Electron Lifetimes. Langmuir 2010, 26, 2592-2598.

(17) Liu, J.; Zhou, D.; Wang, F.; Fabregat-Santiago, F.; Miralles, S. G.; Jing, X.; Bisquert, J.; Wang, P. Joint Photophysical and Electrical Analyses on the Influence of Conjugation Order in D- $\pi$-A Photosensitizers of Mesoscopic Titania Solar Cells. J. Phys. Chem. C 2011, 115, 14425-14430.

(18) Tsao, H. N.; Yi, C.; Moehl, T.; Yum, J.; Zakeeruddin, S. M.; Nazeeruddin, M. K.; Grätzel, M. Cyclopentadithiophene Bridged Donor - Acceptor Dyes Achieve High Power Conversion Efficiencies in Dye-Sensitized Solar Cells Based on the tris - Cobalt Bipyridine Redox Couple. ChemSusChem 2011, 4, 591-594.

(19) Yella, a.; Lee, H.-W.; Tsao, H. N.; Yi, C.; Chandiran, a. K.; Nazeeruddin, M. K.; Diau, E. W.-G.; Yeh, C.-Y.; Zakeeruddin, S. M.; Gratzel, M. Porphyrin-Sensitized Solar Cells with Cobalt (II/III)Based Redox Electrolyte Exceed 12\% Efficiency. Science 2011, 334, 629-634.

(20) Bai, Y.; Yu, Q.; Cai, N.; Wang, Y.; Zhang, M.; Wang, P. Highefficiency Organic Dye-Sensitized Mesoscopic Solar Cells with a Copper Redox Shuttle. Chem. Commun. 2011, 47, 4376-4378.

(21) Hattori, S.; Wada, Y.; Yanagida, S.; Fukuzumi, S. Blue Copper Model Complexes with Distorted Tetragonal Geometry Acting as Effective Electron-Transfer Mediators in Dye-Sensitized Solar Cells. J. Am. Chem. Soc. 2005, 127, 9648-9654.

(22) Brugnati, M.; Caramori, S.; Cazzanti, S.; Marchini, L.; Argazzi, R.; Bignozzi, C. A. Electron Transfer Mediators for Photoelectrochemical Cells Based on $\mathrm{Cu}(\mathrm{I})$ Metal Complexes. Int. J. Photoenergy 2007, 2007, 80756.

(23) Cong, J.; Kinschel, D.; Daniel, Q.; Safdari, M.; Gabrielsson, E.; Chen, H.; Svensson, P. H.; Sun, L.; Kloo, L. Bis(1, 1-bis(2pyridyl)ethane)copper(i/ii) as an Efficient Redox Couple for Liquid Dye-sensitized Solar Cells. J. Mater. Chem. A 2016, 4, 14550-14454.

(24) Freitag, M.; Giordano, F.; Yang, W.; Pazoki, M.; Hao, Y.; Zietz, B.; Grätzel, M.; Hagfeldt, A.; Boschloo, G. Copper Phenanthroline as a Fast and High-Performance Redox Mediator for Dye-Sensitized Solar Cells. J. Phys. Chem. C 2016, 120, 9595-9603.

(25) Michaels, H.; Benesperi, I.; Edvinsson, T.; Muñoz-Garcia, A. B.; Pavone, M.; Boschloo, G.; Freitag, M. Copper Complexes with Tetradentate Ligands for Enhanced Charge Transport in DyeSensitized Solar Cells. Inorganics 2018, 6, 53.

(26) Constable, E. C.; Redondo, A. H.; Housecroft, C. E.; Neuburger, M.; Schaffner, S. Copper(I) Complexes of 6,6'disubstituted 2,2'-bipyridine Dicarboxylic Acids: New Complexes 
for Incorporation into Copper-based Dye sensitized Solar Cells (DSCs). Dalton Trans 2009, 0, 6634-6644.

(27) Freitag, M.; Daniel, Q.; Pazoki, M.; Sveinbjörnsson, K.; Zhang, J.; Sun, L.; Hagfeldt, A.; Boschloo, G. High-efficiency Dye-sensitized Solar Cells with Molecular Copper Phenanthroline as Solid Hole Conductor. Energy Environ. Sci. 2015, 8, 2634-2637.

(28) Saygili, Y.; Söderberg, M.; Pellet, N.; Giordano, F.; Cao, Y.; Muñoz-García, A. B.; Zakeeruddin, S. M.; Vlachopoulos, N.; Pavone, M.; Boschloo, G.; Kavan, L.; Moser, J.-E.; Grätzel, M.; Hagfeldt, A.; Freitag, M. Copper Bipyridyl Redox Mediators for Dye-Sensitized Solar Cells with High Photovoltage. J. Am. Chem. Soc. 2016, 138, 15087-15096.

(29) Freitag, M.; Teuscher, J.; Saygili, Y.; Zhang, X.; Giordano, F.; Liska, P.; Hua, J.; Zakeeruddin, S. M.; Moser, J.-E.; Grätzel, M.; Hagfeldt, A. Dye-sensitized Solar Cells for Efficient Power Generation Under Ambient Lighting. Nat. Photonics 2017, 11, 372-378.

(30) Cao, Y.; Saygili, Y.; Ummadisingu, A.; Teuscher, J.; Luo, J.; Pellet, N.; Giordano, F.; Zakeeruddin, S. M.; Moser, J.-E.; Freitag, M.; Hagfeldt, A.; Grätzel, M. 11\% Efficiency Solid-state Dye-sensitized Solar Cells with Copper(II/I) Hole Transport Materials. Nat. Commun. 2017, 8, 15390.

(31) Ferdowsi, P.; Saygili, Y.; Zakeeruddin, S. M.; Mokhtari, J.; Grätzel, M.; Hagfeldt, A.; Kavan, L. Alternative Bases to 4-tertbutylpyridine for Dye-sensitized Solar Cells Employing Copper Redox Mediator. Electrochim. Acta 2018, 265, 194-201.

(32) Kavan, L.; Saygili, Y.; Freitag, M.; Zakeeruddin, S. M.; Hagfeldt, A.; Grätzel, M. Electrochemical Properties of $\mathrm{Cu}(\mathrm{II} / \mathrm{I})$-Based Redox Mediators for Dye-Sensitized Solar Cells. Electrochim. Acta 2017, 227, 194-202.

(33) Hoffeditz, W. L.; Katz, M. J.; Deria, P.; Cutsail, G. E., III; Pellin, M. J.; Farha, O. K.; Hupp, J. T. One Electron Changes Everything. A Multispecies Copper Redox Shuttle for Dye-Sensitized Solar Cells. J. Phys. Chem. C 2016, 120, 3731-3740.

(34) Magni, M.; Giannuzzi, R.; Colombo, A.; Cipolla, M. P.; Dragonetti, C.; Caramori, S.; Carli, S.; Grisorio, R.; Suranna, G. P.; Bignozzi, C. A.; Roberto, D.; Manca, M. Tetracoordinated Bisphenanthroline Copper-Complex Couple as Efficient Redox Mediators for Dye Solar Cells. Inorg. Chem. 2016, 55, 5245-5253.

(35) Leandri, V.; Daniel, Q.; Chen, H.; Sun, L.; Gardner, J. M.; Kloo, L. Electronic and Structural Effects of Inner Sphere Coordination of Chloride to a Homoleptic Copper(II) Diimine Complex. Inorg. Chem. 2018, 57, 4556-4562.

(36) Ellis, H.; Vlachopoulos, N.; Haggman, L.; Perruchot, C.; Jouini, M.; Boschloo, G.; Hagfeldt, A. PEDOT Counter Electrodes for Dyesensitized Solar Cells Prepared by Aqueous Micellar Electrodeposition. Electrochim. Acta 2013, 107, 45-51.

(37) Fabregat-Santiago, F.; Bisquert, J.; Garcia-Belmonte, G.; Boschloo, G.; Hagfeldt, A. Influence of Electrolyte in Transport and Recombination in Dye-sensitized Solar Cells Studied by Impedance Spectroscopy. Sol. Energy Mater. Sol. Cells 2005, 87, 117-131.

(38) Becke, A. D. Density-functional Thermochemistry. III. The Role of Exact Exchange. J. Chem. Phys. 1993, 98, 5648-5652.

(39) Tomasi, J.; Mennucci, B.; Cammi, R. Quantum Mechanical Continuum Solvation Models. Chem. Rev. 2005, 105, 2999-3094.

(40) Grimme, S.; Ehrlich, S.; Goerigk, L. Effect of the Damping Function in Dispersion Corrected Density Functional Theory. J. Comput. Chem. 2011, 32, 1456-1465.

(41) Ochterski, J. W. Thermochemistry in Gaussian; Gaussian: Wallingford, CT, USA, 2000.

(42) Yanai, T.; Tew, D. P.; Handy, N. C. A New Hybrid ExchangeCorrelation Functional Using the Coulomb-Attenuating Method (CAM-B3LYP). Chem. Phys. Lett. 2004, 393, 51-57.

(43) Jacquemin, D.; Perpète, E. A.; Scuseria, G. E.; Ciofini, I.; Adamo, C. TD-DFT Performance for the Visible Absorption Spectra of Organic Dyes: Conventional versus Long-Range Hybrids. J. Chem. Theory Comput. 2008, 4, 123-135.

(44) Kaupp, M.; Schleyer, P.v. R.; Stoll, H.; Preuss, H. Pseudopotential Approaches to Ca, Sr, and Ba Hydrides. Why Are
Some Alkaline Earth MX2 Compounds Bent? J. Chem. Phys. 1991, 94, $1360-1366$.

(45) Francl, M. M.; Pietro, W. J.; Hehre, W. J.; Binkley, J. S.; Gordon, M. S.; DeFrees, D. J.; Pople, J. A. Self-Consistent Molecular Orbital Methods. XXIII. A Polarization-type Basis Set for Second-row Elements. J. Chem. Phys. 1982, 77, 3654-3665.

(46) Tian, H.; Gabrielsson, E.; Lohse, P. W.; Vlachopoulos, N.; Kloo, L.; Hagfeldt, A.; Sun, L. Development of an Organic Redox Couple and Organic Dyes for Aqueous Dye-sensitized Solar Cells. Energy Environ. Sci. 2012, 5, 9752-9755.

(47) Eriksson, S. K.; Josefsson, I.; Ellis, H.; Amat, A.; Pastore, M.; Oscarsson, J.; Lindblad, R.; Eriksson, A. I. K.; Johansson, E. M. J.; Boschloo, G.; Hagfeldt, A.; Fantacci, S.; Odelius, M.; Rensmo, H. Geometrical and Energetical Structural Changes in Organic Dyes for Dye-sensitized Solar Cells Probed Using Photoelectron Spectroscopy and DFT. Phys. Chem. Chem. Phys. 2016, 18, 252-260.

(48) Cappel, U. B.; Feldt, S. M.; Schöneneboom, J.; Hagfeldt, A.; Boschloo, G. The Influence of Local Electric Fields on Photoinduced Absorption in Dye-sensitized Solar Cells. J. Am. Chem. Soc. 2010, 132, 9096-9101.

(49) Ardo, S.; Sun, Y.; Staniszewski, A.; Castellano, F. N.; Meyer, G. J. Stark Effects After Excited-state Interfacial Electron Transfer at Sensitized TiO2 Nanocrystallites. J. Am. Chem. Soc. 2010, 132, 66966709.

(50) Yum, J.-H.; Baranoff, E.; Kessler, F.; Moehl, T.; Ahmad, S.; Bessho, T.; Marchioro, A.; Ghadiri, E.; Moser, J.-E.; Yi, C.; Nazeeruddin, M. K.; Grätzel, M. A Cobalt Complex Redox Shuttle for Dye-sensitized Solar Cells with High Open-Circuit Potentials. Nat. Commun. 2012, 3, 631-639.

(51) Moehl, T.; Tsao, H. N.; Wu, K.-L.; Hsu, H.-C.; Chi, Y.; Ronca, E.; De Angelis, F.; Nazeeruddin, M. K.; Grätzel, M. High OpenCircuit Voltages: Evidence for a Sensitizer-Induced TiO2 Conduction Band Shift in Ru(II)-Dye Sensitized Solar Cells. Chem. Mater. 2013, 25, 4497-4502.

(52) Mosconi, E.; Yum, J.-H.; Kessler, F.; Gómez García, C. J.; Zuccaccia, C.; Cinti, A.; Nazeeruddin, M. K.; Grätzel, M.; De Angelis, F. Cobalt Electrolyte/Dye Interactions in Dye-Sensitized Solar Cells: A Combined Computational and Experimental Study. J. Am. Chem. Soc. 2012, 134, 19438-19453.

(53) Hagberg, D. P.; Edvinsson, T.; Marinado, T.; Boschloo, G.; Hagfeldt, A.; Sun, L. A Novel Organic Chromophore for Dyesensitized Nanostructured Solar Cells. Chem. Commun. 2006, 21, 2245-2247.

(54) Ellis, H.; Schmidt, I.; Hagfeldt, A.; Wittstock, G.; Boschloo, G. Influence of Dye Architecture of Triphenylamine Based Organic Dyes on the Kinetics in Dye-Sensitized Solar Cells. J. Phys. Chem. C 2015, 119, 21775-21783.

(55) Xu, Y.; Schoonen, M. The Absolute Energy Positions of Conduction and Valence Bands of Selected Semiconducting Minerals. Am. Mineral. 2000, 85, 543-556. 


\section{SUPPORTING INFORMATION}

The Effect of Coordination Sphere Geometry of Copper Redox Mediators on Regeneration and Recombination Behavior in Dye-Sensitized Solar Cell Applications

Yasemin Saygili ${ }^{1}$, Marko Stojanovic ${ }^{2}$, Hannes Michaels ${ }^{3}$, Jan Tiepelt ${ }^{2}$, Joel Teuscher ${ }^{4}$, Arianna Massaro $^{5}$, Michele Pavone ${ }^{5}$, Fabrizio Giordano ${ }^{2}$, Shaik M. Zakeeruddin ${ }^{1}$, Gerrit Boschloo $^{3}$, Jacques-E. Moser ${ }^{4}$, Michael Grätzel ${ }^{2}$, Ana B. Muñoz-García ${ }^{6 *}$, Anders Hagfeldt ${ }^{1 *}$ and Marina Freitag ${ }^{3 *}$

${ }^{1}$ Laboratory of Photomolecular Science, Institute of Chemical Sciences and Engineering, École Polytechnique Fédérale de Lausanne, 1015, Lausanne, Switzerland.

${ }^{2}$ Laboratory for Photonics and Interfaces, Institute of Chemical Sciences, Engineering École Polytechnique Fédérale de Lausanne, 1015 Lausanne, Switzerland

${ }^{3}$ Department of Chemistry-Angström Laboratory, Uppsala University, 75120 Uppsala, Sweden

${ }^{4}$ Photochemical Dynamics Group, Ecole Polytechnique Fédérale de Lausanne, 1015 Lausanne, Switzerland

${ }^{5}$ Department of Chemical Sciences, University of Naples Federico II, 80126 Naples, Italy

${ }^{6}$ Department of Physics “Ettore Pancini”, University of Naples Federico II, 80126 Naples, Italy

* corresponding authors:

marina.freitag@kemi.uu.se, anders.hagfeldt@epfl.ch, anabelen.munozgarcia@unina.it 


\section{Synthetic procedures.}
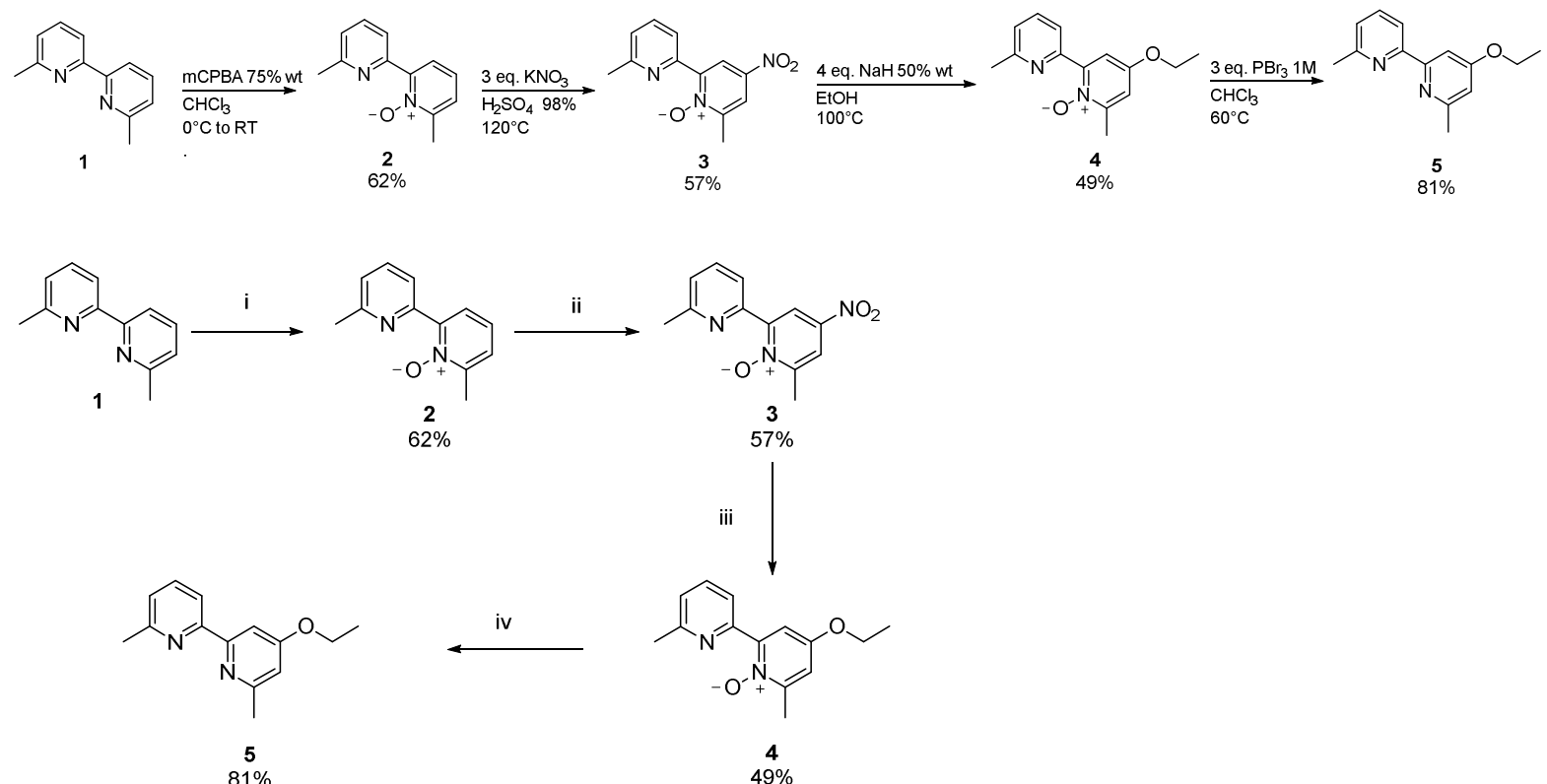

Figure S1. Synthetic procedure of eto='4-ethoxy-6,6'-dimethyl-2,2'-bipyridine' ligand. Conditions: (i): 1 eq. mCPBA $75 \%$ wt, $\mathrm{CHCl}_{3}, 0^{\circ} \mathrm{C}$ to RT, o.n., $62 \%$; (ii): 3 eq. $\mathrm{KNO}_{3}, \mathrm{H}_{2} \mathrm{SO}_{4} 98 \%, 120^{\circ} \mathrm{C}$, o.n., $57 \%$; (iii): 4 eq. $\mathrm{NaH}$ $50 \%$ wt, $\mathrm{EtOH}, 100^{\circ} \mathrm{C}$, o.n., $49 \%$; (iv) 3 eq. $\mathrm{PBr}_{3} 1 \mathrm{M}, \mathrm{CHCl}_{3}, 60^{\circ} \mathrm{C}$, o.n., $81 \%$.

Synthesis of 6,6'-dimethyl-[2,2'-bipyridine] 1-oxide (2)<smiles>Cc1cccc(-c2cccc(C)n2)n1</smiles>

1

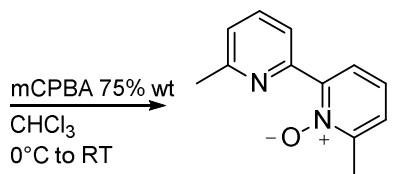

2

6,6'-dimethyl-2,2'-bipyridine(1) (1.2 g, $6.51 \mathrm{mmol}, 1.0$ eq.) was dissolved in $5 \mathrm{~mL}$ chloroform and cooled down to $0^{\circ} \mathrm{C}$ with an ice bath. Then, mCPBA $(2.02 \mathrm{~g}(75 \% \mathrm{wt}), 6.51 \mathrm{mmol}, 1.0$ eq.) in $15 \mathrm{~mL}$ chloroform was added dropwise over 2 hours. Once the addition completed, the ice bath was removed and the reaction mixture allowed to warm up to RT before stirring overnight. After that, chloroform was washed with saturated sodium carbonate $(3 \times 20 \mathrm{~mL})$ and dried over magnesium sulfate. The product used without further purification for the next step $(0.809 \mathrm{~g}, 62 \%)$.

${ }^{1} \mathrm{H}$ NMR (400 MHz, Chloroform- $\left.d\right) \delta 8.58(\mathrm{~d}, J=7.9 \mathrm{~Hz}, 1 \mathrm{H}), 8.00(\mathrm{dd}, J=7.1,3.0 \mathrm{~Hz}, 1 \mathrm{H}), 7.72(\mathrm{t}, J=7.8$ $\mathrm{Hz}, 1 \mathrm{H}), 7.34-7.25(\mathrm{~m}, 2 \mathrm{H}), 7.21(\mathrm{~d}, J=7.7 \mathrm{~Hz}, 1 \mathrm{H}), 2.64(\mathrm{~s}, 3 \mathrm{H}), 2.61(\mathrm{~s}, 3 \mathrm{H})$.

${ }^{13} \mathrm{C}$ NMR (101 MHz, Chloroform- $d$ ) $\delta 177.41,158.04,149.85,149.73,147.83,136.31,125.63(\mathrm{~d}, J=1.7 \mathrm{~Hz})$, 125.04, 123.61, 122.54, 24.60, 18.46.

Mass Spectrometry $\left(\mathrm{APPI}^{+}, \mathrm{m} / z\right):\left[\mathrm{M}+\mathrm{H}^{+}\right]$calculated: 201.1022 found: 201.1020

Synthesis of 6,6'-dimethyl-4-nitro-[2,2'-bipyridine] 1-oxide (3)<smiles></smiles>

2<smiles>CO[n+]1c(C)cc([N+](=O)[O-])cc1-c1cccc(CCCCO[Na])n1</smiles>

3 
6,6'-dimethyl-[2,2'-bipyridine] 1-oxide (2) (0.778 g, $3.89 \mathrm{mmol}, 1.0$ eq.) and potassium nitrate (1.178 g, 11.66 mmol, 3.0 eq.) were charged in a round bottom flask equipped with a condenser. Then, $5 \mathrm{~mL}$ Sulfuric acid $98 \%$ were added and the mixture stirred until dissolution of the solids. The obtained yellow solution was heated at $120^{\circ} \mathrm{C}$ over night. The reaction flask was then cooled down to RT, poured over ice and basified with a solution of sodium hydroxide $6 \mathrm{M}$. The obtained solid was filtered off and dried on the bench. The product was obtained as a beige solid $0.544 \mathrm{~g}(57 \%)$ and was used without further purification.

${ }^{1} \mathrm{H}$ NMR (400 MHz, Chloroform- $\left.d\right) \delta 8.98(\mathrm{~d}, J=3.2 \mathrm{~Hz}, 1 \mathrm{H}), 8.61(\mathrm{~d}, J=7.9 \mathrm{~Hz}, 1 \mathrm{H}), 8.13(\mathrm{~d}, J=3.3 \mathrm{~Hz}$, $1 \mathrm{H}), 7.77(\mathrm{t}, J=7.8 \mathrm{~Hz}, 1 \mathrm{H}), 7.30(\mathrm{~d}, J=7.3 \mathrm{~Hz}, 1 \mathrm{H}), 2.68(\mathrm{~s}, 3 \mathrm{H}), 2.66(\mathrm{~s}, 3 \mathrm{H})$.

${ }^{13} \mathrm{C}$ NMR (101 MHz, Chloroform-d) $\delta 158.75,151.65,147.64,136.67,124.72,123.04,122.16,120.08,118.65$, $118.17,24.60,18.75$.

Mass Spectrometry $\left(\mathrm{APPI}^{+}, \mathrm{m} / z\right):\left[\mathrm{M}+\mathrm{H}^{+}\right]$calculated: 246.0873 found: 246.0872

Synthesis of 4-ethoxy-6,6'-dimethyl-[2,2'-bipyridine] 1-oxide (4)

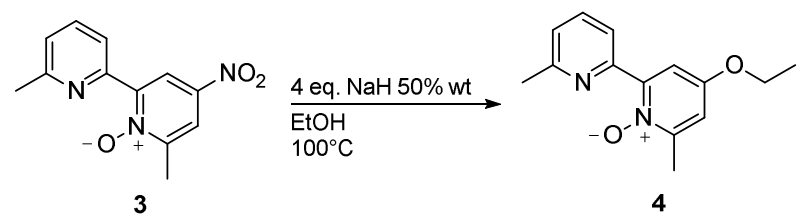

Sodium hydride $(0.338 \mathrm{~g}(50 \% \mathrm{wt}), 7.06 \mathrm{mmol}, 4.0$ eq.) was charged in an over dried schlenk tube under Argon atmosphere. Then, $4 \mathrm{~mL}$ anhydrous Ethanol were slowly added under vigorous stirring and was left at RT until Hydrogen evolution stopped. Then, (6,6'-dimethyl-4-nitro-[2,2'-bipyridine] 1-oxide (3) (0.433 g, 1.77 mmol, 1.0 eq.) was added and the beige suspension was heated to $100^{\circ} \mathrm{C}$ overnight. The reaction mixture was cooled down to RT and diluted with water. The aqueous phase was washed with Chloroform $(3 \times 30 \mathrm{~mL})$ and dried over magnesium sulfate. Finally, evaporation of the solvent afforded a green solid as the desired product $0.210 \mathrm{~g}$ $(49 \%)$.

${ }^{1} \mathrm{H}$ NMR (400 MHz, Chloroform- $d$ ) $\delta 8.67(\mathrm{~d}, J=7.9 \mathrm{~Hz}, 1 \mathrm{H}), 7.71(\mathrm{t}, J=8.1,1 \mathrm{H}), 7.55(\mathrm{~d}, J=3.6 \mathrm{~Hz}, 1 \mathrm{H})$, $7.21(\mathrm{~d}, J=7.7 \mathrm{~Hz}, 1 \mathrm{H}), 6.85(\mathrm{~d}, J=3.6 \mathrm{~Hz}, 1 \mathrm{H}), 4.33-4.03(\mathrm{~m}, 2 \mathrm{H}), 2.63(\mathrm{~s}, 3 \mathrm{H}), 2.59(\mathrm{~s}, 3 \mathrm{H}), 1.46(\mathrm{td}, J=$ 7.0, $1.4 \mathrm{~Hz}, 3 \mathrm{H})$.

${ }^{13} \mathrm{C}$ NMR (101 MHz, Chloroform-d) $\delta 157.90,155.94,150.56,149.78,148.13,136.28,123.67,122.73,112.70$, $110.69,64.33,24.64,18.84,14.55$.

Mass Spectrometry $\left(\mathrm{ESI}^{+}, \mathrm{m} / \mathrm{z}\right):\left[\mathrm{M}+\mathrm{H}^{+}\right]$calculated: 245.1285 found: 245.1285

Synthesis of 4-ethoxy-6,6'-dimethyl-2,2'-bipyridine (5)

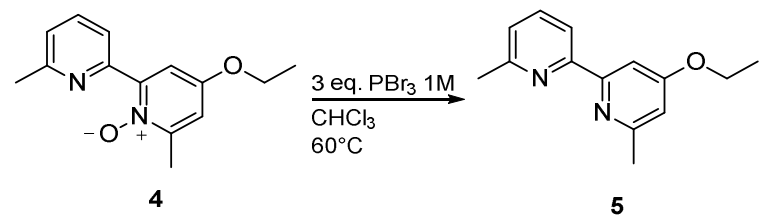

4-ethoxy-6,6'-dimethyl-[2,2'-bipyridine] 1-oxide(4) (0.210 g, $0.86 \mathrm{mmol}, 1.0 \mathrm{eq}$.$) was charged in an oven dried$ round bottom flask brought under Argon and dissolved in $5 \mathrm{~mL}$ Chloroform and cooled down to $0^{\circ} \mathrm{C}$ with an ice bath. Then, Phosphorus tribormide (1.0 M in dichloromethane) $(2.58 \mathrm{~mL}, 2.58 \mathrm{mmol}, 3.0$ eq.) was added dropwise to the mixture. The reaction was then warmed up to RT and heated at $60^{\circ} \mathrm{C}$ for 24 hours. After that, the obtained suspension was poured over ice and basified with sodium hydroxyde $6 \mathrm{M}$ to afford the formation of a beige solid, which was removed by vacuum filtration. The remaining filtrate was then washed with Chloroform $(3 \times 10 \mathrm{~mL})$ and dried over magnesium sulfate. Evaporation of the solvent afforded the desired product as a beige solid $0.159 \mathrm{~g}(81 \%)$

${ }^{1} \mathrm{H}$ NMR (400 MHz, Chloroform- $d$ ) $\delta 8.18(\mathrm{~d}, J=7.8 \mathrm{~Hz}, 1 \mathrm{H}), 7.78(\mathrm{~d}, J=2.3 \mathrm{~Hz}, 1 \mathrm{H}), 7.74-7.66(\mathrm{~m}, 1 \mathrm{H})$, $7.17(\mathrm{~d}, J=7.7 \mathrm{~Hz}, 1 \mathrm{H}), 6.70(\mathrm{~d}, J=2.3 \mathrm{~Hz}, 1 \mathrm{H}), 4.21(\mathrm{qd}, J=7.0,1.9 \mathrm{~Hz}, 2 \mathrm{H}), 2.65$ (s, 3H), 2.59 (s, 3H), 1.48 $(\mathrm{td}, J=7.0,1.9 \mathrm{~Hz}, 3 \mathrm{H})$.

${ }^{13} \mathrm{C}$ NMR (101 MHz, Chloroform- $d$ ) $\delta 166.25,159.31,157.74(\mathrm{~d}, J=1.9 \mathrm{~Hz}), 155.83,136.98(\mathrm{~d}, J=5.1 \mathrm{~Hz})$, $123.12,118.34,118.18,109.77,104.40,63.46,24.77,24.69,14.63$.

Mass Spectrometry $\left(\mathrm{ESI}^{+}, \mathrm{m} / \mathrm{z}\right):\left[\mathrm{M}+\mathrm{H}^{+}\right]$calculated: 229.1330 found: 229.1335 


\section{Synthesis of copper 4-ethoxy-6,6'-dimethyl-2,2'-bipyridine $\left[\mathrm{Cu}(\text { eto })_{2}\right][\mathrm{TFSI}](6)$ and $\left[\mathrm{Cu}(\mathrm{eto})_{2}\right][\mathrm{TFSI}]_{2}$ (7) (Figure S2)}

For $\left[\mathrm{Cu}(\text { eto })_{2}\right][\mathrm{TFSI}](6)$, one equivalent of $\mathrm{CuI}(27.8 \mathrm{mg}, 0.139 \mathrm{mmol})$ was mixed with 3 equivalents of 4ethoxy-6,6'-dimethyl-2,2'-bipyridine $(95.8 \mathrm{mg}, 0.42 \mathrm{mmol})$ in $20 \mathrm{ml}$ ethanol, under nitrogen atmosphere, at room temperature for 2 hours. The resulted complex was obtained as intense red, crystalline powder. The product was filtered and redissolved by addition of $5 \mathrm{ml}$ of deionized water followed by an addition of 5 equivalents of LiTFSI (200 mg, $0.7 \mathrm{mmol})$. The solution was further stirred for 2 hours at room temperature and under nitrogen atmosphere resulting in red precipitation. The complex (6) was collected by filtration and washed with water. The yield of the products was $85.6 \%(\mathrm{~mol})$.

${ }^{1} \mathrm{H}$ NMR (400 MHz, Chloroform- $d$ ) $\delta 8.14(\mathrm{dd}, J=8.3,3.7 \mathrm{~Hz}, 1 \mathrm{H}), 8.00(\mathrm{dt}, J=10.9,5.4 \mathrm{~Hz}, 1 \mathrm{H}), 7.64(\mathrm{~s}$, $1 \mathrm{H}), 7.44(\mathrm{dd}, J=7.9,3.6 \mathrm{~Hz}, 1 \mathrm{H}), 6.93(\mathrm{~s}, 1 \mathrm{H}), 4.39-4.19(\mathrm{~m}, 2 \mathrm{H}), 2.24(\mathrm{dd}, J=21.2,3.8 \mathrm{~Hz}, 6 \mathrm{H}), 1.54(\mathrm{dt}, J$ $=10.8,5.0 \mathrm{~Hz}, 3 \mathrm{H})$.

${ }^{13} \mathrm{C}$ NMR (101 MHz, Chloroform- $\left.d\right) \delta 166.70,158.70,157.03,153.16,151.81,138.18,125.71,119.28,111.19$, 106.59, 64.77, 25.24, 25.09, 14.43 .

Mass Spectrometry $\left(\mathrm{ESI}^{+}, \mathrm{m} / \mathrm{z}\right)$ : calculated: 519.1821 found: $519.121\left[\mathrm{Cu}(\mathrm{eto})_{2}\right]^{1+}$

Elemental Analysis: Measured N 8.016 (\%);C 44.341 (\%);H 4.146 (\%);Calculated N 8.75 (\%);C 45.02 (\%);H $4.03(\%)$

For $\left[\mathrm{Cu}(\text { eto })_{2}\right][\mathrm{TFSI}]_{2}$ (7): One equivalent of $\mathrm{CuCl}_{2}(19.6 \mathrm{mg}, 0.1 \mathrm{mmol})$ was mixed with 3 equivalents of 4ethoxy-6,6'-dimethyl-2,2'-bipyridine $(67 \mathrm{mg}, 0.3 \mathrm{mmol})$ in $20 \mathrm{ml}$ ethanol, under nitrogen atmosphere, at room temperature for 2 hours. The resulted complex was obtained as green solution. Addition of $5 \mathrm{ml}$ of deionized water followed by an addition of 5 equivalents of LiTFSI ( $145 \mathrm{mg}, 0.5 \mathrm{mmol})$. The solution was further stirred for 2 hours at room temperature and under nitrogen atmosphere resulting in green precipitation. The complex (7) was collected by filtration and washed with water. The average yield was $63.4 \%$ (mol). The product was collected as green powder.

Mass Spectrometry $\left(\mathrm{ESI}^{+}, \mathrm{m} / z\right)$ : calculated: 519.1821 found: $519.189\left[\mathrm{Cu}(\text { eto })_{2}\right]^{2+}$

Elemental Analysis: Measured N 8.212 (\%);C 43. 015 (\%);H 3.972 (\%);Calculated N 7.78(\%);C 35.57 (\%);H $2.99(\%)$ 

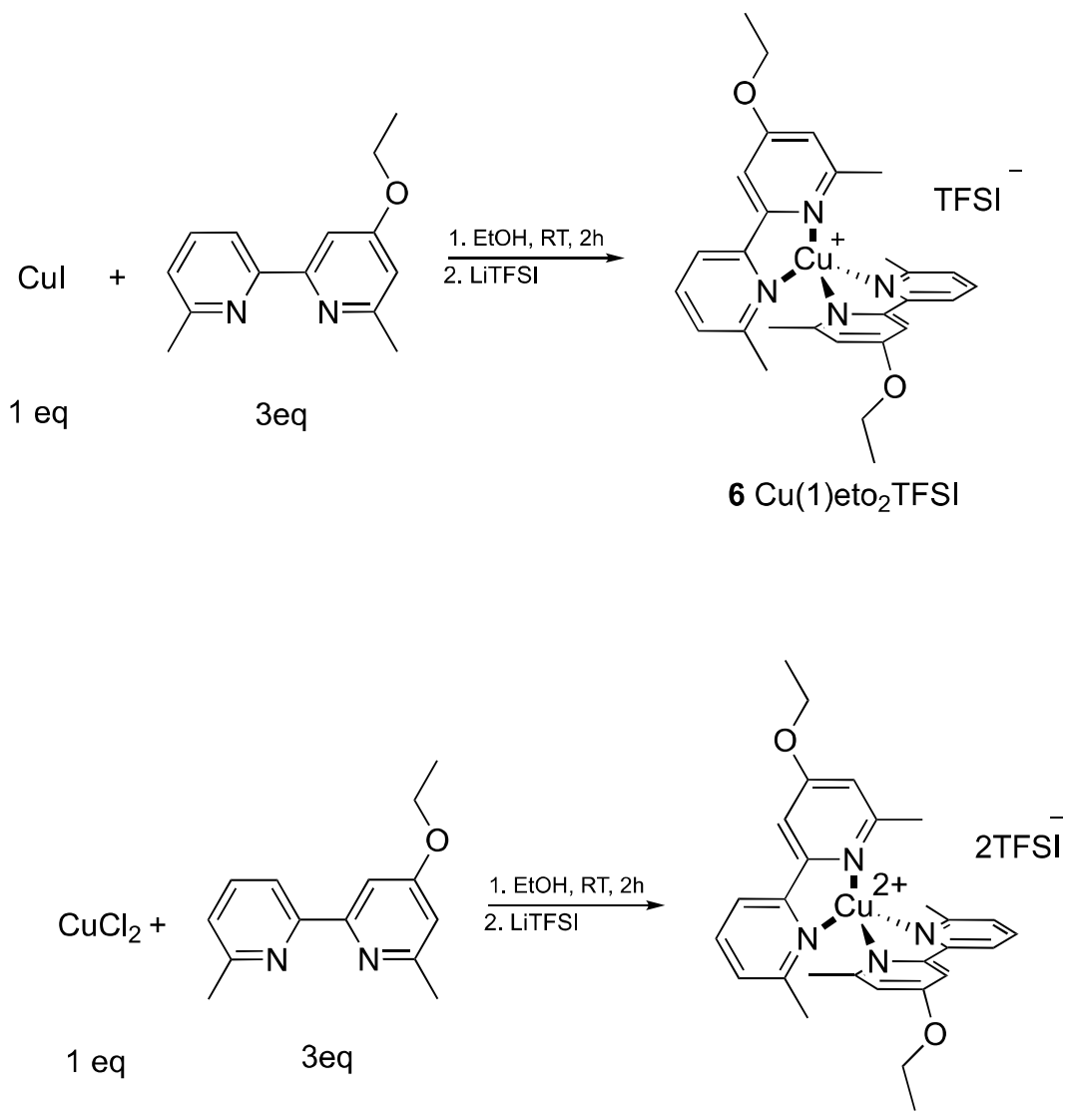

$7 \mathrm{Cu}(2)$ eto $_{2} \mathrm{TFSI}_{2}$

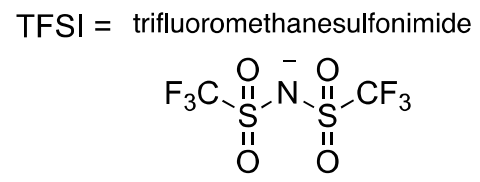

Figure S2. Synthetic procedure for $\left[\mathrm{Cu}(\text { eto })_{2}\right][\mathrm{TFSI}]$ and $\left[\mathrm{Cu}(\text { eto })_{2}\right][\mathrm{TFSI}]_{2}$ 


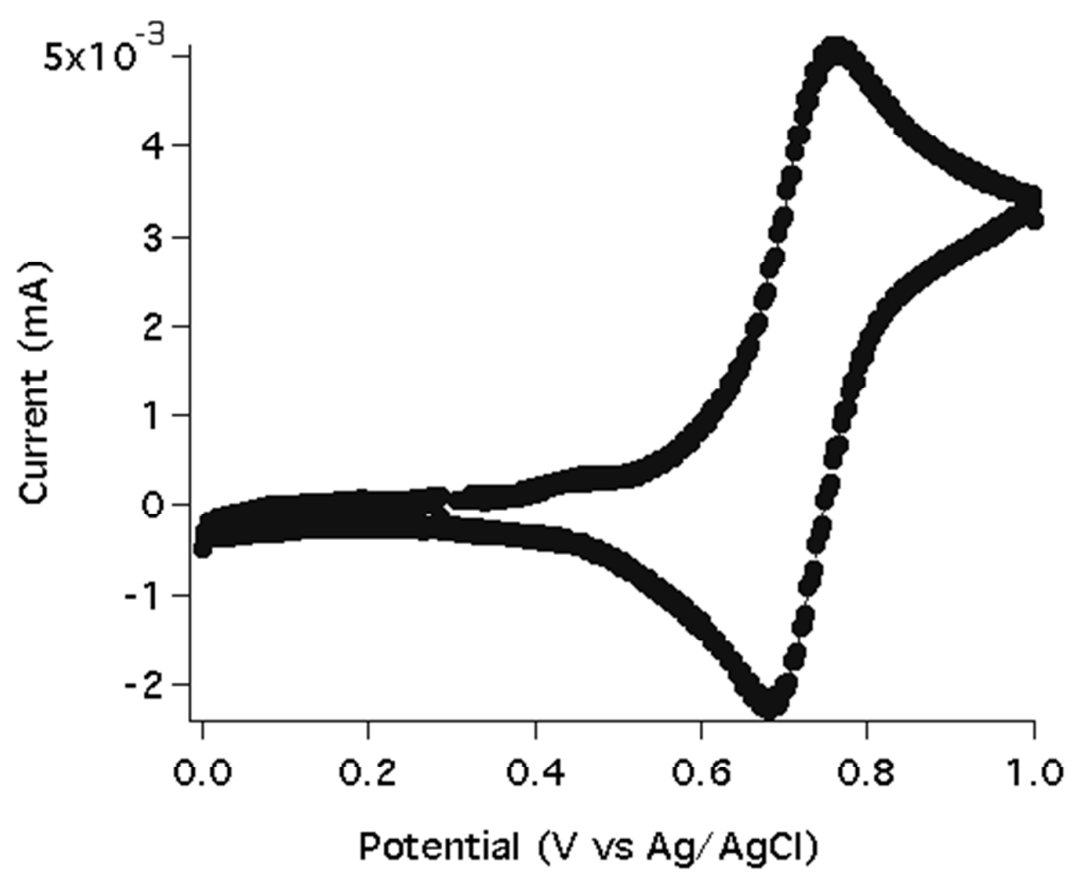

Figure S3. Cyclic Voltagramm of $\left[\mathrm{Cu}(\text { eto })_{2}\right]^{1+}$ complex.

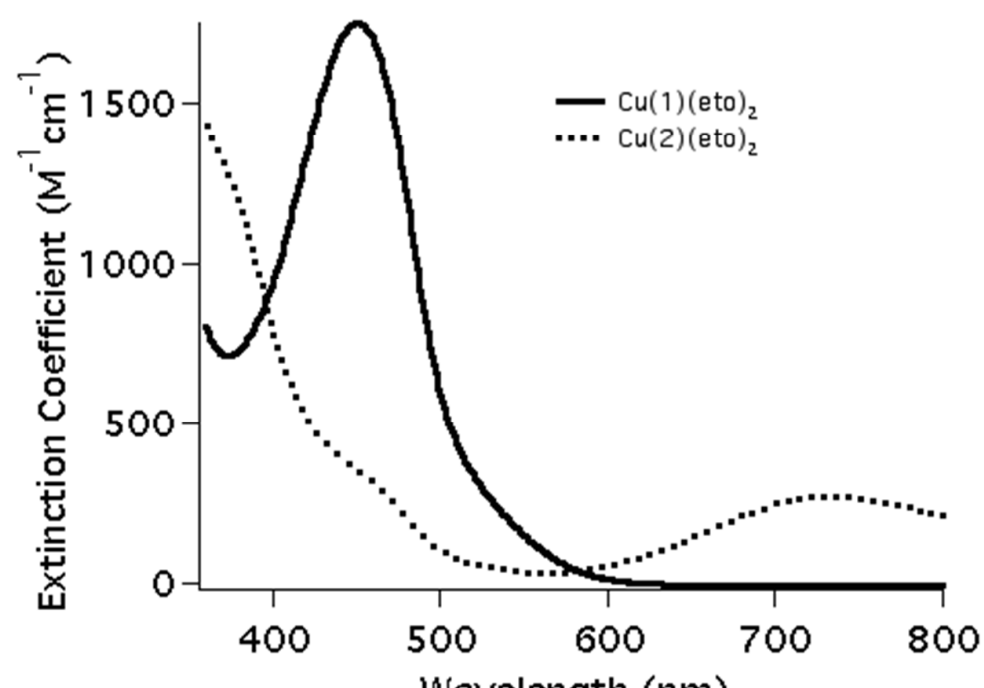

Figure S4. Molecular extinction coefficients of $\left[\mathrm{Cu}(\text { eto })_{2}\right]^{1+}$ and $\left[\mathrm{Cu}(\text { eto })_{2}\right]^{2+}$ complexes. 
a.\#

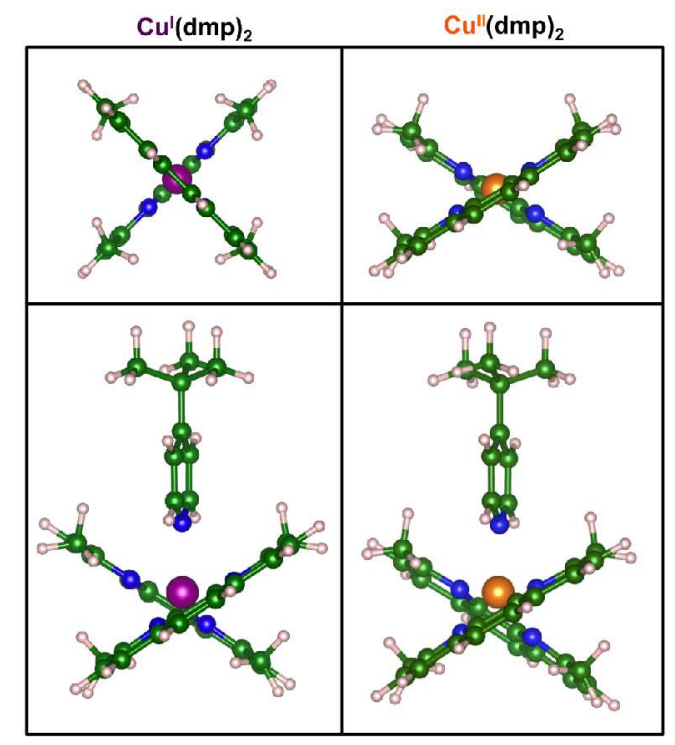

b.

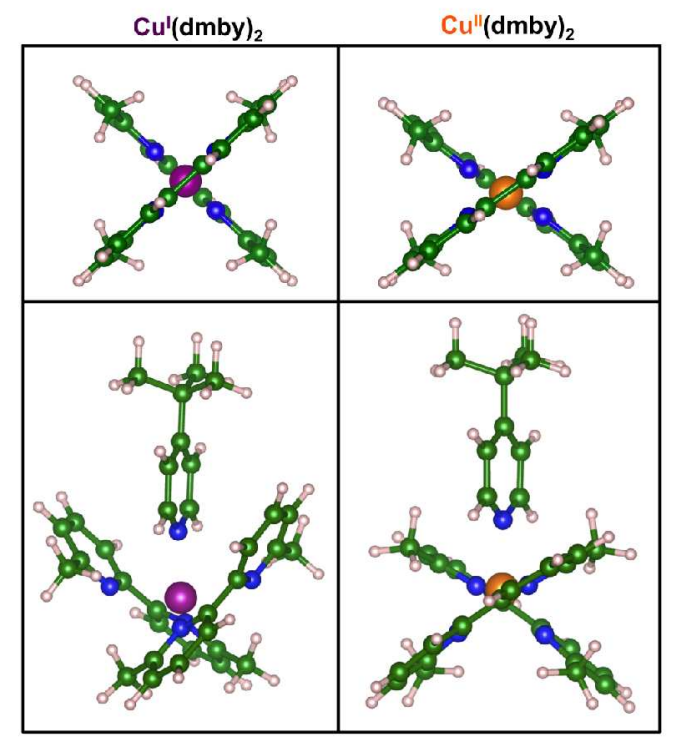

Figure S5. a) $\left[\mathrm{Cu}(\mathrm{dmp})_{2}\right]^{1+}$ (left) and $\left[\mathrm{Cu}(\mathrm{dmp})_{2}\right]^{2+}$ (right) b) $\quad\left[\mathrm{Cu}(\mathrm{dmby})_{2}\right]^{1+}$ (left) and $\left[\mathrm{Cu}(\mathrm{dmby})_{2}\right]^{2+}$ (right) minimum-energy structures without and with TBP (top and bottom, respectively) calculated at the DFTB3LYP-D3BJ level of theory in Acetonitrile (PCM). 